\title{
Swimming pool heating technology: A state-of-the-art review
}

\author{
Yantong Li ${ }^{1,2}(\varangle)$, Natasa Nord ${ }^{2}$, Gongsheng Huang ${ }^{1}$, Xin Li ${ }^{1}$ \\ 1. Department of Architecture and Civil Engineering, City University of Hong Kong, Tat Chee Avenue, Kowloon, Hong Kong, China \\ 2. Department of Energy and Process Engineering, Norwegian University of Science and Technology, Trondheim, Norway
}

\begin{abstract}
A large amount of heat is needed to maintain the thermal comfort of both indoor and outdoor swimming pools in cold seasons. This motivates the development of various heating technologies aiming to reduce energy use, as well as operating and investment costs. Although their development can be traced back to the 1960s, a comprehensive review of these technologies is lacking. Therefore, this paper presents a comprehensive review of the development of heating technologies for swimming pools. This review firstly introduces available heat transfer models that can be used to calculate or predict heat loss and heat gain for swimming pools. Then, different passive and active technologies are summarized. The active heating technologies used for indoor swimming pools include solar collector, heat pump, waste heat recovery, geothermal energy, and congregation technologies. The active heating technologies used for outdoor swimming pools include solar collector, heat pump, PCM storage, geothermal energy, biomass heater, and waste heat recovery technologies. A discussion is presented on the practical and possible heating techniques for swimming pool applications. Finally, through the reviewed literature, future research opportunities are identified, to guide researchers to investigate swimming pool heating systems with suitable and relevant technologies.
\end{abstract}

\section{Keywords}

swimming pool,

heating supply,

solar energy,

heat pump,

phase change material

\section{Article History}

Received: 15 January 2020

Revised: 11 May 2020

Accepted: 25 May 2020

(c) Author(s) 2020

\section{Introduction}

Energy is a basic requirement of modern life (Xie et al. 2018; $\mathrm{Li}$ et al. 2020c) and also the precondition for the development of industries in many respects, including agriculture, transportation, telecommunication, digitalization, etc. Since the industrial revolution in the 1760 s, energy demand has been rapidly increasing, due to economic and social developments, together with sustained population growth and rapid urbanization (Drissi Lamrhari and Benhamou 2018; Du et al. 2017; Harkouss et al. 2018; Li et al. 2019). The energy crisis is becoming more and more serious, as fossil fuels are continuously utilized, leading to environmental pollution problems (e.g. global warming and ozone depletion) (Du et al. 2018, 2020). Hence, different policies have been proposed to improve energy efficiency, increase the use of renewable energy resources, and reduce greenhouse gas emissions. The European Union has set goals in its "2030 Climate and Energy Framework" for energy efficiency to be increased by at least 32.5\% from 2021 to
2030 (EU 2020), and for the share of renewable energy to be increased to at least 32\% from 2021 to 2030 (EU 2020). In addition, by 2030, greenhouse gas emissions will be cut by at least $40 \%$ from the 1990 levels (EU 2020). In their "Renewable Energy Law", the Chinese government has proposed increasing the contribution of renewable energies in electricity generation to $22.16 \%$ (Sakah et al. 2017). Furthermore, in their 2020 project, the Korean government has enacted the goal of increasing renewable energies' contribution to more than $20 \%$ of the total amount by 2030 (Kim et al. 2018).

Energy use in buildings comprises around 30\% to $40 \%$ of the total worldwide energy use (Berardi and Soudian 2018; Hong et al. 2018; Uribe et al. 2018). Sports facilities are one of the categories of buildings with the largest energy demand. Compared with other sports facilities, swimming pools have higher energy demand for pool water heating, ventilation, spacing heating, and operation of circulation pumps (Kampel et al. 2013). The annual energy use of a swimming pool facility varies from $600 \mathrm{kWh} / \mathrm{m}^{2}$ to $6,000 \mathrm{kWh} / \mathrm{m}^{2}$, related to the

E-mail: yantong.li@ntnu.no 


\begin{tabular}{|c|c|c|c|}
\hline \multicolumn{4}{|c|}{ List of symbols } \\
\hline$A_{\mathrm{m}}$ & pool area of each swimmer when the number of & $R_{\mathrm{B}}$ & Bowen ratio $(-)$ \\
\hline & swimmers is maximum $\left(\mathrm{m}^{2}\right)$ & $R_{\mathrm{a}}$ & relative humidity (\%) \\
\hline$A_{\mathrm{p}}$ & surface area of the pool $\left(\mathrm{m}^{2}\right)$ & $S_{\mathrm{r}}$ & specific humidity of room air (-) \\
\hline$A_{\mathrm{s}}$ & surface area of the conduction to ground $\left(\mathrm{m}^{2}\right)$ & $S_{\mathrm{w}}$ & specific humidity of saturated air at water surface $(-)$ \\
\hline$c$ & a constant in Table $2\left(\mathrm{~W} /\left(\mathrm{m}^{2} \cdot \mathrm{Pa}\right)\right)$ & $T_{\mathrm{a}}$ & temperature of ambient air $\left({ }^{\circ} \mathrm{C}\right)$ \\
\hline$c_{\mathrm{c}}$ & cloudiness factor $(-)$ & $T_{\text {dew }}$ & dew point temperature $\left({ }^{\circ} \mathrm{C}\right)$ \\
\hline$c_{\mathrm{s}}$ & specific heat of the soil $(\mathrm{J} /(\mathrm{kg} \cdot \mathrm{K}))$ & $T_{\mathrm{p}}$ & water temperature of the pool $\left({ }^{\circ} \mathrm{C}\right)$ \\
\hline$c_{\mathrm{w}}$ & specific heat of the water $(\mathrm{J} /(\mathrm{kg} \cdot \mathrm{K}))$ & $T_{\mathrm{rf}}$ & temperature of refilling fresh water $\left({ }^{\circ} \mathrm{C}\right)$ \\
\hline$d$ & a constant in Table $2\left(\mathrm{~W} \cdot \mathrm{s} /\left(\mathrm{m}^{3} \cdot \mathrm{Pa}\right)\right)$ & $T_{\mathrm{s}}$ & temperature of the soil $\left({ }^{\circ} \mathrm{C}\right)$ \\
\hline$E_{\mathrm{e}}$ & water evaporation rate of the pool $\left(\mathrm{kg} /\left(\mathrm{s} \cdot \mathrm{m}^{2}\right)\right)$ & $T_{\text {sky }}$ & sky temperature $\left({ }^{\circ} \mathrm{C}\right)$ \\
\hline$F_{\mathrm{a}}$ & utilization factor of the pool $(-)$ & $T_{\text {surf }}$ & upper surface temperature of the ambient environment \\
\hline$G_{s}$ & solar irradiation $\left(\mathrm{W} / \mathrm{m}^{2}\right)$ & & $\left({ }^{\circ} \mathrm{C}\right)$ \\
\hline$H_{\mathrm{e}}$ & latent heat resulting from water evaporation $(\mathrm{J} / \mathrm{kg})$ & $T_{\mathrm{w}}$ & water surface temperature $\left({ }^{\circ} \mathrm{C}\right)$ \\
\hline$h_{\mathrm{cv}}$ & convective heat transfer coefficient $\left(\mathrm{W} /\left(\mathrm{m}^{2} \cdot \mathrm{K}\right)\right)$ & $t$ & time $(s)$ \\
\hline$h_{\mathrm{e}}$ & evaporative heat transfer coefficient $\left(\mathrm{W} /\left(\mathrm{m}^{2} \cdot \mathrm{Pa}\right)\right)$ & $V_{\mathrm{p}}$ & volume of the pool $\left(\mathrm{m}^{3}\right)$ \\
\hline$K_{\mathrm{e}}$ & a constant determined by density difference $(-)$ & $w_{\mathrm{a}}$ & wind speed parallel to the water surface $(\mathrm{m} / \mathrm{s})$ \\
\hline$k$ & thermal conductivity $(\mathrm{W} /(\mathrm{m} \cdot \mathrm{K}))$ & $w_{\mathrm{e}}$ & a coefficient in Table $1(\mathrm{~m} / \mathrm{s})$ \\
\hline$k_{\mathrm{s}}$ & thermal conductivity of the soil $(\mathrm{W} /(\mathrm{m} \cdot \mathrm{K}))$ & $x$ & distance beneath the ground $(\mathrm{m})$ \\
\hline$L_{\mathrm{c}}$ & characteristic length of the pool for calculating & $z$ & a constant in Table $2(-)$ \\
\hline & convective heat loss $(\mathrm{m})$ & $\varepsilon_{\mathrm{w}}$ & emissivity of the water $(-)$ \\
\hline$L_{\mathrm{s}}$ & characteristic length of the pool for calculating & $\rho_{\mathrm{r}}$ & density of the room air $\left(\mathrm{kg} / \mathrm{m}^{3}\right)$ \\
\hline & conductive heat loss $(\mathrm{m})$ & $\rho_{\mathrm{s}}$ & density of the soil $\left(\mathrm{kg} / \mathrm{m}^{3}\right)$ \\
\hline$m_{\mathrm{rf}}$ & mass flowrate of refilling fresh water $(\mathrm{kg} / \mathrm{s})$ & $\rho_{\text {sw }}$ & density of the saturated air at water surface $\left(\mathrm{kg} / \mathrm{m}^{3}\right)$ \\
\hline$N_{\mathrm{e}}$ & number of swimmers $(-)$ & $\rho_{\mathrm{w}}$ & density of the water $\left(\mathrm{kg} / \mathrm{m}^{3}\right)$ \\
\hline $\mathrm{Nu}$ & Nusselt number $(-)$ & $\sigma_{\text {io }}$ & a constant for distinguishing the ISPs and OSPs (-) \\
\hline$n$ & a constant in Table $1(-)$ & $\sigma_{\mathrm{s}}$ & Stefan-Boltzmann constant $\left(\mathrm{kW} /\left(\mathrm{m}^{2} \cdot \mathrm{K}^{4}\right)\right)$ \\
\hline$p_{a}$ & partial vapor pressure of the ambient air $(\mathrm{Pa})$ & $\gamma_{\mathrm{e}}$ & a constant in Table $1(-)$ \\
\hline & saturated vapor pressure at water surface $(\mathrm{Pa})$ & & \\
\hline$Q_{\mathrm{cn}}$ & heat loss from conduction (W) & Abbre & iations \\
\hline$Q_{\mathrm{cv}}$ & heat loss from convection (W) & & \\
\hline$Q_{e}$ & heat loss from evaporation (W) & CFD & computational fluid dynamics \\
\hline$Q_{\mathrm{r}}$ & heat loss from radiation $(\mathrm{W})$ & ISP & indoor swimming pool \\
\hline$Q_{\mathrm{rf}}$ & heat loss from refilling water $(\mathrm{W})$ & OSP & outdoor swimming pool \\
\hline$Q_{s}$ & dimensionless conduction heat rate $(-)$ & PCM & phase change material \\
\hline$R a$ & Rayleigh number (一) & & \\
\hline
\end{tabular}

volume and area of the pool, operation schedule, location, weather, and types (Trianti-Stourna et al. 1998). The major energy use of swimming pool facilities is for heating. The heating purposes for indoor swimming pool (ISP) and outdoor swimming pool (OSP) facilities differ.

People can swim at any time of the entire year in ISPs, and swimming activities are unaffected by outdoor weather conditions. The heat is required not only to maintain a comfortable water temperature but also to ensure indoor thermal comfort levels. Water evaporation will increase the indoor humidity, resulting in an increase in ventilation requirements (Rajagopalan and Jamei 2015). Thus, there is a requirement for heat to be provided to warm the inducing outdoor air. Kampel et al. (2013) collected the data of the annual energy use of 41 Norwegian ISP facilities from 1998 to 2011. They concluded that the average annual energy use of the Norwegian ISP facilities was around $3,991 \mathrm{kWh} / \mathrm{m}^{2}$. They also reported that the climate was not the main factor that affected the energy use of the swimming pool facilities, but the water use of the pool had a strong relationship with the energy use of the facilities (Kampel et al. 2016).

For OSPs, during the summer season, the high outdoor temperature and solar irradiation can ensure a comfortable pool temperature. However, during the cold season, especially in subtropical climate regions, the OSP is closed due to the undesirable weather (Li et al. 2020a). In some high-density 
cities like Hong Kong, the resource of space is very precious, and thus the closure of the OSP will lead to the waste of the space. Therefore, to increase the available opening times for OSPs in the cold season, heating is required. Mousia and Dimoudi (2015) evaluated the energy use of OSPs in Greece, based on the data collected from questionnaires, surveys, and the General Secretary of Sports. They found that most staff used conventional heating technologies (e.g. oil or gas boilers) to satisfy the OSPs' heating demands. The results of their data analysis showed that the average annual energy use of an OSP was $2,456.16 \mathrm{kWh} / \mathrm{m}^{2}$, when a thermalinsulation cover was not adopted, and $1,827.45 \mathrm{kWh} / \mathrm{m}^{2}$, when a thermal-insulation cover was adopted. It could be concluded that the energy use was high when traditional heating technologies were adopted to supply heat for the swimming pool facilities. Therefore, it is necessary to adopt advanced heating technologies for swimming pool facilities. However, to the best of the authors' knowledge, a comprehensive review of suitable and advanced heating technologies adopted for swimming pool facilities is lacking. There is an urgent necessity to fill the knowledge gaps in developing heat transfer models for swimming pools and the design and operation of swimming pool heating systems.

This paper therefore presents an overview of advanced heating technologies for swimming pools. Firstly, the mathematical models, which were developed to describe the heat transfer processes in swimming pools, including heat loss from evaporative, convective, conductive, radiative, refilling water, and heat gained from the sun are summarized. A variety of empirical equations and approaches to describe the main components of the swimming pool model are presented. Secondly, the technologies utilized in swimming pool heating systems are classified into passive and active technologies. The active technologies are classified into ISP and OSP heating technologies. ISP heating technologies include solar collector, heat pump, waste heat recovery, and geothermal energy technologies. OSP heating technologies include solar collector, heat pump, PCM storage, geothermal heat storage, biomass heater, and waste heat recovery technologies. A discussion is presented on the practical and possible heating techniques for both ISPs and OSPs. Finally, future research opportunities are proposed, to guide scholars to develop suitable and relevant swimming pool heating systems.

The rest of the paper is organized as follows. The heat transfer model of the swimming pool is described in Section 2. Passive swimming pool heating technologies are presented in Section 3, while Section 4 shows active swimming pool heating technologies. Section 5 gives the practical and possible heating techniques for swimming pool applications, and Section 6 presents the concluding remarks and possible future research opportunities.

\section{Heat transfer model of the swimming pool}

A swimming pool heat transfer model is the basic requirement for investigating the performance of swimming pool heating systems. It is proposed to describe the water variation of the pool with the total heat flux of the pool, which is composed of heat obtained from the sun and heat loss from evaporation, convection, conduction, radiation, and refilling water. The mathematical formula of this model has been presented in the studies of Ruiz and Martínez (2010) and Woolley et al. (2011), and it is expressed as:

$\rho_{\mathrm{w}} \cdot c_{\mathrm{w}} \cdot V_{\mathrm{p}} \cdot \frac{\mathrm{d} T_{\mathrm{p}}}{\mathrm{d} t}=\sigma_{\mathrm{io}} \cdot Q_{\mathrm{s}}-Q_{\mathrm{e}}-Q_{\mathrm{cv}}-Q_{\mathrm{cn}}-Q_{\mathrm{r}}-Q_{\mathrm{rf}}$

where $\rho_{\mathrm{w}}$ and $c_{\mathrm{w}}$ are the density and specific heat of the water, respectively; $V_{\mathrm{p}}$ and $T_{\mathrm{p}}$ are the volume and water temperature of the pool, respectively; $\sigma_{\text {io }}$ is a constant for distinguishing ISPs and OSPs. For ISPs, $\sigma_{\text {io }}$ is 0 , while for OSPs, $\sigma_{\text {io }}$ is $1 . Q_{\mathrm{s}}$ is the heat obtained from the sun; $Q_{\mathrm{e}}, Q_{\mathrm{cv}}$, $Q_{\mathrm{cn}}, Q_{\mathrm{r}}$, and $Q_{\mathrm{rf}}$ are the heat loss from the evaporation, convection, conduction, radiation, and refilling water, respectively; and $t$ represents the time. Each of the abovementioned heat gain and loss items are described below in detail.

\subsection{Evaporative heat loss}

The evaporative heat loss $\left(Q_{\mathrm{e}}\right)$ is caused by the conversion of the liquid water of the pool to gaseous water. The calculations of the $Q_{\mathrm{e}}$ of ISPs and OSPs differ and thus are explained separately as follows.

\section{(a) Evaporative heat loss in ISPs}

For ISPs, $Q_{\mathrm{e}}$ is calculated according to the water evaporation rate $\left(E_{\mathrm{e}}\right)$, expressed below:

$Q_{\mathrm{e}}=H_{\mathrm{e}} \cdot A_{\mathrm{p}} \cdot E_{\mathrm{e}}$

where $A_{\mathrm{p}}$ represents the surface area of the pool; and $H_{\mathrm{e}}$ represents the latent heat resulting from the water evaporation. Since the $E_{\mathrm{e}}$ in an occupied pool differs from that in an unoccupied pool, different empirical equations are used to calculate $E_{\mathrm{e}}$ for occupied and unoccupied pools, as summarized in Table 1 , where the coefficient $\left(w_{\mathrm{e}}\right)$ is determined by the following equation (Hanssen and Mathisen 1990):

$w_{\mathrm{e}}=\left[w_{\mathrm{a}}^{2}+\left(0.12 \cdot\left(4 \cdot\left(1-R_{\mathrm{a}}\right)-\left(T_{\mathrm{a}}-T_{\mathrm{w}}\right)\right)^{0.5}\right)^{2}\right]^{0.5}$

where $w_{\mathrm{a}}$ represents the wind speed parallel to the water surface; $R_{\mathrm{a}}$ represents the relative humidity; $T_{\mathrm{a}}$ represents 
Table 1 Summary of empirical equations of the $E_{\mathrm{e}}$

\begin{tabular}{ccc}
\hline References & Equations (unoccupied pools) & Equations (occupied pools) \\
\hline Hanssen and Mathisen 1990 & $E_{\mathrm{e}}=3 \times 10^{-5} \cdot w_{\mathrm{e}}^{1 / 3} \cdot\left(\mathrm{e}^{0.06 T_{\mathrm{w}}}-R_{\mathrm{a}} \cdot \mathrm{e}^{0.06 T_{\mathrm{a}}}\right)$ & - \\
Shah 2003, 2014 (general forms) & $E_{\mathrm{e}}=\gamma_{\mathrm{e}} \cdot(\Delta p)^{n}$ & - \\
Shah 2002, 2003 & $E_{\mathrm{e}}=K_{\mathrm{e}} \cdot \rho_{\mathrm{sw}} \cdot\left(\rho_{\mathrm{r}}-\rho_{\mathrm{sw}}\right)^{\frac{1}{3}} \cdot\left(S_{\mathrm{w}}-S_{\mathrm{r}}\right)$ & $E_{\mathrm{e}}=0.113-\frac{7.9 \times 10^{-5}}{F_{\mathrm{a}}}+5.9 \times 10^{-5} \cdot \Delta p$ \\
Shah 2012 & $\left(\left(\rho_{\mathrm{r}}-\rho_{\mathrm{sw}}\right)>0\right)$ & - \\
\hline
\end{tabular}

the ambient air temperature; and $T_{\mathrm{w}}$ represents the water surface temperature.

In Table $1, \Delta p$ represents the difference between saturated vapor pressure at the water surface and partial vapor pressure of the room air; and $F_{\mathrm{a}}$ represents the utilization factor of the pool, calculated by the following equation (Shah 2003):

$F_{\mathrm{a}}=N_{\mathrm{e}} \cdot A_{\mathrm{m}} / A_{\mathrm{p}}$

where $A_{\mathrm{m}}$ represents the pool area of each swimmer when the number of swimmers is maximum; $N_{\mathrm{e}}$ represents the number of swimmers; $K_{\mathrm{e}}$ is a constant determined by the difference between the room air density $\left(\rho_{\mathrm{r}}\right)$ and the saturated air density at water surface $\left(\rho_{\text {sw }}\right) ; K_{\mathrm{e}}$ is 35 when $\left(\rho_{\mathrm{r}}-\rho_{\mathrm{sw}}\right)>$ 0.02 and $K_{\mathrm{e}}$ is 40 when $\left(\rho_{\mathrm{r}}-\rho_{\mathrm{sw}}\right) \leq 0.02$ (Shah 2002, 2003); $S_{\mathrm{w}}$ and $S_{\mathrm{r}}$ represent the specific humidity of the saturated air at the water surface and room air, respectively; and $\gamma_{\mathrm{e}}$ and $n$ are constants that differ in different studies (Shah 2003, 2014).

In addition to the empirical equations summarized in Table 1, different studies have been conducted to investigate the evaporation phenomenon in ISPs. Asdrubali (2009) established a swimming pool scale model in a climatic chamber. The water evaporation ratio in different environmental conditions was obtained and used to develop a new predication model. Lu et al. (2014) adopted neural networks to forecast the water evaporation rate in a swimming pool facility in Finland. Furthermore, a computational fluid dynamics (CFD)-based approach was developed for calculating the water evaporation rate in the swimming pool facility (Blázquez et al. 2017, 2018). Water evaporation had a significant effect on the thermal-moisture status of the ISP facilities. An experimental study on the thermal-moisture environment in an ISP facility in different air variables was presented in the study of Ciuman and Lipska (2018). Limane et al. $(2017,2018)$ utilized OpenFOAM to model the mass and heat transfer process in an ISP facility. They concluded that the swimmers had an important influence on the indoor environment in the swimming pool facility.

\section{(b) Evaporative heat loss in OSPs}

For OSPs, the evaporative heat loss $\left(Q_{\mathrm{e}}\right)$ is calculated adopting a semi-empirical correlation that includes the vapor pressure difference and evaporative heat transfer coefficient, shown as the following equation (Ruiz and Martínez 2010):

$Q_{\mathrm{e}}=h_{\mathrm{e}} \cdot A_{\mathrm{p}} \cdot\left(p_{\mathrm{s}}-p_{\mathrm{a}}\right)$

where $p_{\mathrm{s}}$ is the saturated vapor pressure at water surface; $p_{\mathrm{a}}$ is the partial vapor pressure of ambient air; and $h_{\mathrm{e}}$ represents the evaporative heat transfer coefficient that is regarded as the empirical function of wind speed, depicted by the following equation:

$h_{\mathrm{e}}=c+d \cdot w_{\mathrm{a}}^{z}$

where $c, d$, and $z$ are the factors that are identified by different scholars, summarized in Table 2 (Ruiz and Martínez 2010; Buonomano et al. 2015).

\subsection{Convective heat loss}

The convective heat loss $\left(Q_{\mathrm{cv}}\right)$ is caused by the heat transfer resulting from the movement of the pool water and ambient air. It is calculated according to the temperature difference between the water surface and ambient air, expressed as the following equation:

$Q_{\mathrm{cv}}=h_{\mathrm{cv}} \cdot A_{\mathrm{p}} \cdot\left(T_{\mathrm{p}}-T_{\mathrm{a}}\right)$

where $h_{\mathrm{cv}}$ is the convective heat transfer coefficient.

In the ISP model, $h_{\mathrm{cv}}$ is calculated according to Newton's law of cooling, depicted as the following equation (Winterton 1999):

Table 2 Different sets of factors for the evaporative heat transfer coefficient (Ruiz and Martínez 2010; Buonomano et al. 2015)

\begin{tabular}{cccc}
\hline Authors & $c\left(\mathrm{~W} /\left(\mathrm{m}^{2} \cdot \mathrm{Pa}\right)\right)$ & $d\left(\mathrm{~W} \cdot \mathrm{s} /\left(\mathrm{m}^{3} \cdot \mathrm{Pa}\right)\right)$ & $z(-)$ \\
\hline Rohwer (1931) & 0.0850 & 0.0508 & 1 \\
McMillan (1971) & 0.0360 & 0.0250 & 1 \\
Richter (1979) & 0.0423 & 0.0565 & 0.5 \\
Smith et al. (1994) & 0.0638 & 0.0669 & 1 \\
ISO TC 180 (1995) & 0.0506 & 0.0669 & 1 \\
ASHRAE (2003) & 0.0890 & 0.0782 & 1 \\
\hline
\end{tabular}


$h_{\mathrm{cv}}=\frac{k \cdot N u}{L_{\mathrm{c}}}$

where $k$ is the thermal conductivity; $L_{\mathrm{c}}$ is the characteristic length of the pool; and $N u$ is the Nusselt number, expressed as the following equation (Bergman et al. 2011):

$N u=0.14 \cdot R a^{1 / 3}$

where $R a$ is the Rayleigh number.

In the OSP model, $h_{\mathrm{cv}}$ is calculated by the following empirical equations:

$h_{\mathrm{cv}}=2.8+3.0 \cdot w_{\mathrm{a}}($ Lam and Chan 2001)

$h_{\mathrm{cv}}=3.1+4.1 \cdot w_{\mathrm{a}}$ (Ruiz and Martínez 2010)

In addition, Woolley et al. (2011) developed a new method that is based on the Bowen formulation (Bowen 1926) to calculate the convective loss, which is expressed as:

$Q_{\mathrm{cv}}=R_{\mathrm{B}} \cdot Q_{\mathrm{e}}$

where $R_{\mathrm{B}}$ is the Bowen ratio, which can be calculated by considering the effect of ambient pressure on the evaporative and convective heat transmission (Bowen 1926).

\subsection{Conductive heat loss}

The conductive heat loss $\left(Q_{\mathrm{cn}}\right)$ mainly results from the temperature difference between the water of the pool and soil. Many studies have indicated that $Q_{\mathrm{cn}}$ is so small in the total heat loss of the pool that it can be neglected. However, Govaer and Zami (1981) reported that, in some cases, $Q_{c n}$ should be considered, for example when there is moist soil or sub-surface water movement, which may lead to a significant increase in conductive loss. They gave the soil temperature profile for calculating the conductive loss by the governing equation, shown as follows:

$\rho_{\mathrm{s}} \cdot c_{\mathrm{s}} \cdot \frac{\partial T_{\mathrm{s}}}{\partial t}=k_{\mathrm{s}} \cdot \frac{\partial^{2} T_{\mathrm{s}}}{\partial x^{2}}$

where $\rho_{\mathrm{s}}, c_{\mathrm{s}}, k_{\mathrm{s}}$, and $T_{\mathrm{s}}$ represent the density, specific heat, thermal conductivity, and temperature of the soil, respectively; and $x$ represents the distance beneath the ground.

In addition, based on the assumption of $T_{\mathrm{s}}$ being uniform and unchanged, $Q_{\mathrm{cn}}$ can be calculated by (Buonomano et al. 2015):

$Q_{\mathrm{cn}}=\frac{1}{2 L_{\mathrm{s}}} \cdot Q_{\mathrm{s}} \cdot k_{\mathrm{s}} \cdot A_{\mathrm{s}} \cdot\left(T_{\mathrm{p}}-T_{\mathrm{s}}\right)$

where $L_{\mathrm{s}}$ is the characteristic length of the pool; $Q_{s}$ is the dimensionless conduction heat rate that can be calculated using shape factors (Bergman et al. 2011); and $A_{s}$ represents the surface area of conduction to ground.

\subsection{Radiative heat loss}

The radiative heat loss $\left(Q_{r}\right)$ is caused by the heat transfer between the pool water and the upper surface of the ambient environment through long-wave radiation. It is expressed as:

$Q_{\mathrm{r}}=A_{\mathrm{p}} \cdot \varepsilon_{\mathrm{w}} \cdot \sigma_{\mathrm{s}} \cdot\left(\left(T_{\mathrm{p}}+273\right)^{4}-\left(T_{\mathrm{sur}}+273\right)^{4}\right)$

where $\varepsilon_{\mathrm{w}}$ represents the emissivity of the water; $\sigma_{\mathrm{s}}$ is the Stefan-Boltzmann constant, which is $5.67 \times 10^{-11} \mathrm{~kW} /\left(\mathrm{m}^{2} \cdot \mathrm{K}^{4}\right)$; and $T_{\text {sur }}$ is the upper surface temperature of the ambient environment. In the ISP model, $T_{\text {sur }}$ is the indoor surrounding surface temperature. In the OSP model, $T_{\text {sur }}$ is the sky temperature $\left(T_{\text {sky }}\right)$, which can be calculated by the correlations in Table 3. $T_{\text {dew }}$ is the dew point temperature; $\varepsilon_{\mathrm{s}}$ is the emissivity of the sky; and $\mathcal{c}_{\mathrm{c}}$ is the cloudiness factor.

\subsection{Refilling water heat loss}

The refilling water heat loss $\left(Q_{\mathrm{rf}}\right)$ is caused by the temperature difference between the water of the pool and the refilling fresh water. The fresh water is required to refill the pool, since the pool water is lost through evaporation and draining. The $Q_{\mathrm{rf}}$ is expressed as (Buonomano et al. 2015):

$Q_{\mathrm{rf}}=c_{\mathrm{w}} \cdot m_{\mathrm{rf}} \cdot\left(T_{\mathrm{p}}-T_{\mathrm{rf}}\right)$

where $T_{\text {rf }}$ represents the temperature of the refilling fresh water; and $m_{\mathrm{rf}}$ represents the mass flowrate of the refilling fresh water. In the study of Buonomano et al. (2015), $T_{\mathrm{rf}}$ was constant at $15{ }^{\circ} \mathrm{C}$. Different examples are presented to discuss the values of $m_{\mathrm{rf}}$. A swimming pool operator's manual showed that Ontario's regulations stated that, for each swimmer, daily, $20 \mathrm{~L}$ of fresh water should be refilled into the pool, and the maximum refilling water volume should be $15 \%$ of the pool's volume (McKeown 2009). Italian standard UNI 10637 stated that the daily refilling water volume of a pool was 5\% of the pool volume (Buonomano et al. 2015). Further, in a book, titled Reform in School Mathematics and Authentic Assessment (Romberg 1995), a

Table 3 Different correlations of the $T_{\text {sky }}$

\begin{tabular}{cc}
\hline References & Correlations \\
\hline Smith et al. 1994 & $T_{\text {sky }}=\left(T_{\mathrm{a}}+273\right) \cdot\left(0.8+T_{\text {dew }} / 250\right)^{0.25}-273$ \\
Ruiz and Martínez & \\
(Buonomano et al. & $T_{\text {sky }}=\left(T_{\mathrm{a}}+273\right) \cdot\left(\varepsilon_{\mathrm{s}}+0.8 \cdot\left(1-\varepsilon_{\mathrm{s}}\right) \cdot c_{\mathrm{c}}\right)^{0.25}-273$ \\
2015) & $T_{\text {sky }}=\left(T_{\mathrm{a}}+273\right) \cdot \varepsilon_{\mathrm{s}}^{0.25}-273$ \\
Woolley et al. 2011 & \\
\hline
\end{tabular}


case study showed that the daily refilling water volume of a pool was $3 \%$ of the pool volume.

\subsection{Heat gained from the sun}

For an ISP, the thermal energy from the sun is absorbed by the buildings, and it will affect the temperature of the room air. The heat transfer between the water of the pool and the room air will be affected. However, the water of the pool cannot be directly obtained from heat from the sun, and thus the heat gained from the sun $\left(Q_{s}\right)$ is not considered in the heat transfer model of the ISP. For an OSP, the thermal energy from the sun can be directly absorbed by the pool. The $Q_{s}$ is expressed by the following equation (Lam and Chan 2001):

$$
Q_{\mathrm{s}}=\alpha_{\mathrm{s}} \cdot G_{\mathrm{s}} \cdot A_{\mathrm{p}}
$$

where $G_{s}$ denotes the solar irradiation; and $\alpha_{\text {s }}$ denotes the solar absorptivity, which is assumed to be 0.85 in the studies of Lam and Chan (2001) and Ruiz and Martínez (2010). However, in the study of Woolley et al. (2011), an annual average absorption coefficient calculated by the approach proposed by Wu et al. (2009) was adopted.

The techniques reviewed in this paper were classified into passive and active techniques for swimming pool applications. This classification was proposed according to the information presented on the website of Varming Consulting Engineers Ltd. (Varming 2020). The difference between the passive and active design applications is presented as follows. The passive design applications use the "natural force" (e.g. sunlight, wind, and gravity) to realize the goals of heating, cooling, and ventilation, and thus no fuel or grid power is utilized. For example, roof ponds can be utilized as a kind of passive heating technique (Sharifi and Yamagata 2015). The active design applications use electricity and fuel, such as solar collectors and wind turbines, to realize the goals of heating, cooling, and ventilation.

3 Passive techniques for swimming pool heating application

The most commonly used passive technique for swimming pools is to use a thermal-insulation cover, which can effectively prevent heat losses, especially regarding evaporation loss. That is to say, a thermal-insulation cover can effectively reduce the heating load of a swimming pool, without using fuel or grid power, and thus it belongs in the passive heating technique category. The suggestion to utilize swimming pool covers was first proposed by Brooks (1955). In 1960, Root (1960) proposed an inflated plastic cover applied to a swimming pool. The cover was inflated and floated on the pool's surface when the pool was not in use and could be deflated and rolled up by a pontoon for storage when the pool was utilized. Czarnecki (1963) tested on-site the performance of an inflated polyvinyl chloride cover, with a thickness of $0.02 \mathrm{~cm}$, used on an OSP in Melbourne, Australia. The author concluded that the strength of the tested cover was not satisfactory and suggested the use of a cover with a thickness of $0.05 \mathrm{~cm}$. Table 4 depicts the thermal properties of the typical material used in thermal-insulation covers.

Comparisons between the performance of opaque and transparent covers have also been studied. Szeicz and Mcmonagle (1983) compared the performance of opaque and transparent covers and concluded that, during the night, an opaque cover was more effective for maintaining the temperature of swimming pools than a transparent cover, because the opaque cover was able to cut down longwave radiation. However, during a sunny day, the use of a transparent cover obtained more thermal energy from the sun than the use of an opaque cover. During a cloudy day, a transparent cover might be less effective than an opaque cover. Furthermore, Francey et al. (1980) reported an on-site study investigating the performance of an air-bubble cover used on an OSP, in which the performance of opaque and transparent covers was compared. They found that the transparent cover was more effective in raising the water temperature than the opaque cover, since it could absorb more sunlight. Figure 1 shows the schematic diagrams of (a) single-layer; (b) inflated; and (c) air-bubble thermalinsulation cover. Inflated and air-bubble thermal-insulation cover might have better thermal preservation performance than single-layer thermal insulation cover, since the thermal resistance of the entire cover might be improved when the air is integrated into the cover.

Table 4 Thermal properties of typical materials used in thermal-insulation covers

\begin{tabular}{ccccc}
\hline Names & Density $\left(\mathrm{kg} / \mathrm{m}^{3}\right)$ & Thermal conductivity $(\mathrm{W} /(\mathrm{m} \cdot \mathrm{K}))$ & Specific heat $(\mathrm{kJ} /(\mathrm{kg} \cdot \mathrm{K}))$ & References \\
\hline Polyvinyl chloride & $1100-1450$ & $0.13-0.28$ & 1.0 & MEPC 2020 \\
High-density polyethylene & $930-970$ & $0.46-0.52$ & 2.3 & MEPC 2020; OMNEXUS 2020 \\
Low-density polyethylene & $910-940$ & 0.33 & 2.3 & MEPC 2020; OMNEXUS 2020 \\
Unnamed plastic & - & 0.08 & - & Szeicz and McMonagle 1983 \\
\hline
\end{tabular}




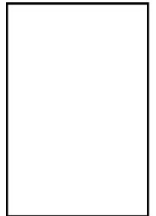

(a)

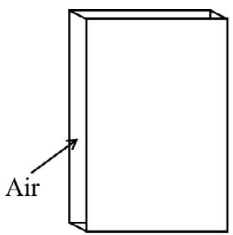

(b)

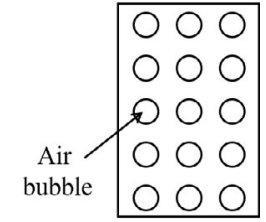

(c)
Fig. 1 (a) Single-layer; (b) inflated; and (c) air-bubble thermalinsulation cover

\section{Active techniques for swimming pool heating application}

This section presents the active techniques for swimming pool heating application, including conventional, indoor, and outdoor swimming pool heating techniques. Conventional swimming pool heating techniques are reviewed to reflect their current problems, demonstrating the urgent requirement for advanced heating techniques. The reviewed advanced techniques are classified into ISP and OSP heating techniques, due to the following differences. Firstly, ISPs operate all year round, and thus ISP heating techniques should be designed to satisfy their annual heating demand. OSPs' active season normally only runs from May to September in subtropical climate regions. To extend the available season of OSPs, OSP heating techniques are designed to satisfy their cold-season heating demands. Secondly, ISP heating techniques are used not only to provide heat for the water of pool but also to satisfy the indoor heating and ventilation demand. OSPs' heating techniques are only used to provide heat for the water of the pool. Generally, the energy consumption of ISPs is relatively higher than that of OSPs because of the high sensible, latent, and ventilation loads in ISPs. Relevant results indicate that the energy use of an ISP is nearly three times greater than that of an OSP of the same size (Trianti-Stourna et al. 1998). It should be noted that the techniques presented in this section are from the currently existing literature.

\subsection{Conventional swimming pool heating techniques}

Conventional swimming pool heating techniques include electric and oil/gas heaters. Electric heaters are used to converse the electricity energy to thermal energy, and then offer the heat to the pool. Oil/gas heaters, also called oil/ gas-fired heaters, are used to burn oil or gas to offer the heat to the pool. Figure 2 shows the schematic diagram of electric and oil/gas heaters for swimming pool heating applications. Compared with oil/gas heaters, electric heaters might be easier to be used. Electric heaters can immediately provide heat for the pool when the power is turned on. Oil/gas heaters generally comprise the fan, burner, and heat exchanger. Ambient air will be input into the burner by fan and mixed with oil. The mixture will be ignited, and the heat will be transfer to the pool by heat exchanger. Compared with other advanced techniques, electric and oil/gas heaters have the advantage of quiet operation, reliability, and low initial investment. However, they have the disadvantage of low coefficient of performance (COP). Hence, in current literature, they were selected as conventional heating techniques, and the performance of systems using them was compared with that using proposed advanced techniques. The performance of systems with conventional heating techniques was related to the price of the electricity, oil, and gas. Detailed information about the price of the electricity, oil, and gas was presented as follows. In the study of Brambley and Wells (1983), gas and oil heaters were used, and the price of gas and oil were $\$ 4.75 / \mathrm{GJ}$ and $\$ 1.20 /$ gal, respectively. Croy and Peuser (1994) used gas and oil heaters, and the price of energy costs was $0.05 \mathrm{DM} / \mathrm{kWh}$ to $0.1 \mathrm{DM} / \mathrm{kWh}$. In the studies of Lam and Chan (2001, 2003) and Chan and Lam (2003), electric and gas heaters were used, and the average price of the electricity and gas in Hong Kong were HK\$0.8/kWh and HK\$0.21/MJ, respectively. Katsaprakakis (2015) used the diesel oil heater, and the annual average price of oil in Greece was $1.35 € /$ lt.

(a)
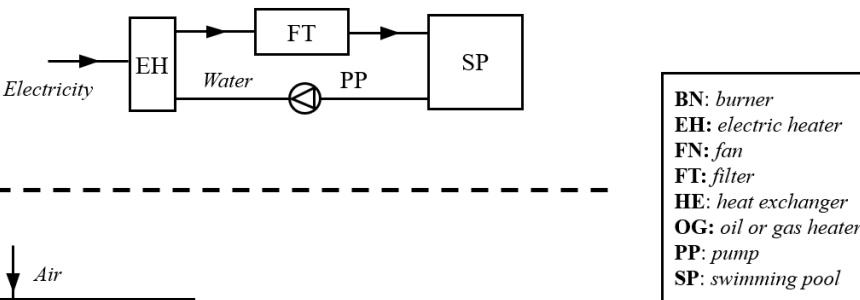

(b)

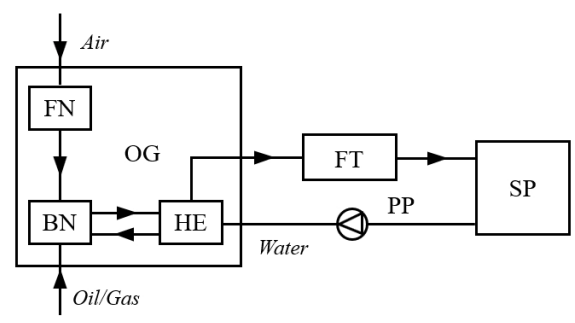

Fig. 2 Schematic diagram of (a) electric and (b) oil/gas heaters for swimming pool heating applications 


\subsection{Indoor swimming pool heating techniques}

ISP heating techniques are utilized to maintain a suitable pool water temperature within a comfortable thermal range and satisfy the indoor thermal comfort requirement. This section presents the current heating techniques applied in ISPs, including solar collector, heat pump, waste heat recovery, and geothermal energy technologies. In the following, a brief overview of the mentioned heat supply technologies is presented.

\subsubsection{Solar collector technology}

As one of the popular renewable energy sources, solar energy has the advantages of cleanness, non-pollution, and reliability. Therefore, it has been applied in many fields, such as building cooling and heating (Feng et al. 2017; Li and Huang 2019; Li et al. 2020d). The solar collector is regarded as one main application of solar energy, which has been extensively utilized to supply heat for ISPs. Figure 3 shows the schematic diagram of an ISP heating system with solar collectors. The water tank is used to store heat from solar collectors, and the stored heat will be released to the ISPs. The "on/off" of the associated pumps of the solar collector can be controlled according to the real-time solar irradiance or the temperature difference between the inlet and outlet water temperature of the solar collector. The "on/off" of other pumps can be controlled by the water temperature of the pool. If the water temperature is lower than the set values (e. g. $27^{\circ} \mathrm{C}$ ), the pumps will be turned on; otherwise, they will be turned off. The heat exchanger is used to improve the quality of the water that will be input to the ISPs. It should be noted that, in some studies, the solar collectors are directly linked with the ISPs, and thus the water tank and heat exchanger might not be needed in the system. Heat collected from solar collectors is directly supplied to the ISPs, contributing to the reduction in heat loss from the water tank and heat exchanger. Singh et al. (1989) developed a simple analytical model for an ISP heating system with solar collectors. Parametric studies on the effect of the solar collector area and heat removal factor on the system performance indicated that the water temperature of an ISP increased as these two factors increased (Singh et al. 1989). It should be noted that heat removal was a factor that was usually used to calculate the useful heat gain of solar collectors (Abdel-Khalik 1976). Tiwari and Sharma (1991) developed an analytical model for calculating the energy efficiency of the ISP heating system. Govaer (1984) analyzed the energy performance of an ISP heating system with solar collectors, using a utilizability method, which was applied to evaluate the utilized thermal energy that could be provided by solar collectors. It was concluded that the utilizability

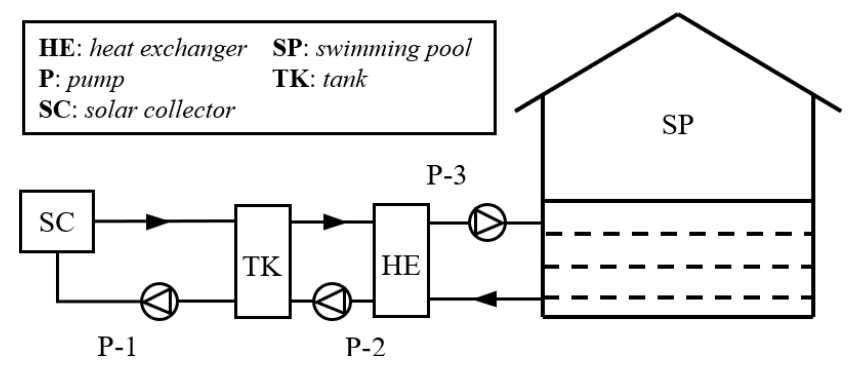

Fig. 3 ISP heating system with solar collectors

theory could be effectively adopted to analyze the energy performance of the system. Regarding economic indicators of solar technologies as a heat supply solution for swimming pools, Brambley and Wells (1983) reported that solar collector technology adopted in the ISP heating system in St. Louis might not be economical in comparison with a conventional system with low-price fuels (e.g. gas), leading to an unacceptable payback period of nearly ten years. However, this fact might be argued, considering the current high requirements for the use of renewables.

The photovoltaic/thermal collector $(\mathrm{PV} / \mathrm{T})$ is an advanced application, which not only absorbs heat from the sun, like solar collectors, but also produces electricity by converting the absorbed thermal energy. The use of PV/Ts in ISPs has been presented by different scholars. Buonomano et al. (2015) utilized PV/Ts to provide heat and electricity for an ISP in Naples, Italy. The surface area and volume of the pool were $600 \mathrm{~m}^{2}$ and $1260 \mathrm{~m}^{3}$. A daily analysis of the system showed that the electricity efficiency of the system was $9 \%$, and the thermal efficiency of the system was related to solar irradiance. Bazilian et al. (2001) presented the design concept for using PV/Ts in ISPs with a maximum heating temperature of $30^{\circ} \mathrm{C}$. The installation of the glazed and unglazed PV/Ts was designed for ISPs. They reported that the payback period of the glazed $\mathrm{PV} / \mathrm{T}$ was short, due to the utilization of low-temperature heat.

\subsubsection{Heat pump technology}

In an ISP, the evaporation of pool water not only reduces the water temperature of the pool but also increases the indoor air humidity. To ensure indoor thermal comfort, ventilation is necessary (Panaras et al. 2018), which leads to a high energy demand for heating the inducing outdoor air. In this case, a heat pump that dehumidifies the air can be used to reduce ventilation load and thus to decrease the energy use in the ISP heating system (Lee and Kung 2008). Figure 4 shows the schematic of problems caused by the evaporation of pool water and the functions of heat pumps in ISP heating system. Heat pumps can be used in different ways in ISPs, including open absorption heat pumps, heat pump dehumidifiers, and solar assisted heat pumps. 


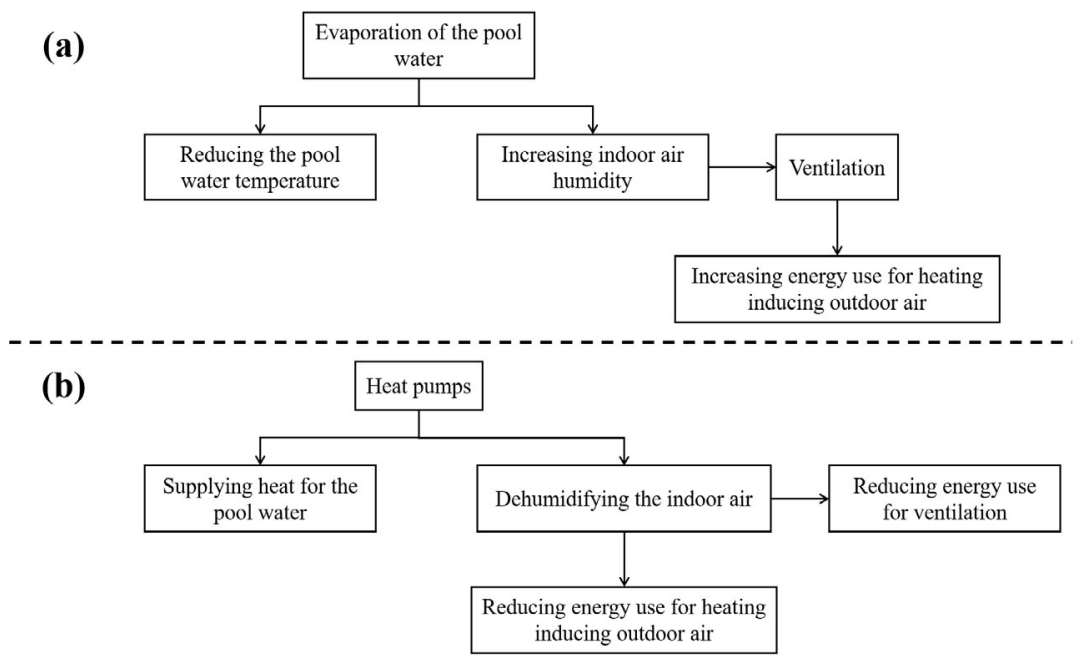

Fig. 4 Schematics of (a) problems caused by evaporation of the pool water; and (b) functions of heat pumps in ISP heating system

\section{(a) Open absorption heat pump}

Figure 5 shows the schematic diagram of an ISP heating system with the absorption heat pump. The system is mainly composed of absorber, evaporator, condenser, expansion valve, generator, pump, and ISP. The absorption medium and refrigerant are used in different cycles. In the absorption medium cycle, the thermal energy is input to the generator. The refrigerant with high pressure is separated from the mixture and it is input to the condenser. The expansion valve will be used to reduce the pressure of the absorption medium. The absorption medium with low pressor will be input to the absorber and it will be mixed with the refrigerant from the evaporator. In the refrigerant cycle, the expansion valve will be used to reduce the pressure of refrigerant from the condenser. The heat obtained from the condenser and absorber will be offered to the ISP. Westerlund and Dahl (1994) developed a heating system with an open absorption heat pump for an ISP, to reduce the heat demand for dehumidification in a heating system. The exhausted air from the ISP facility was dehumidified by the absorber. The

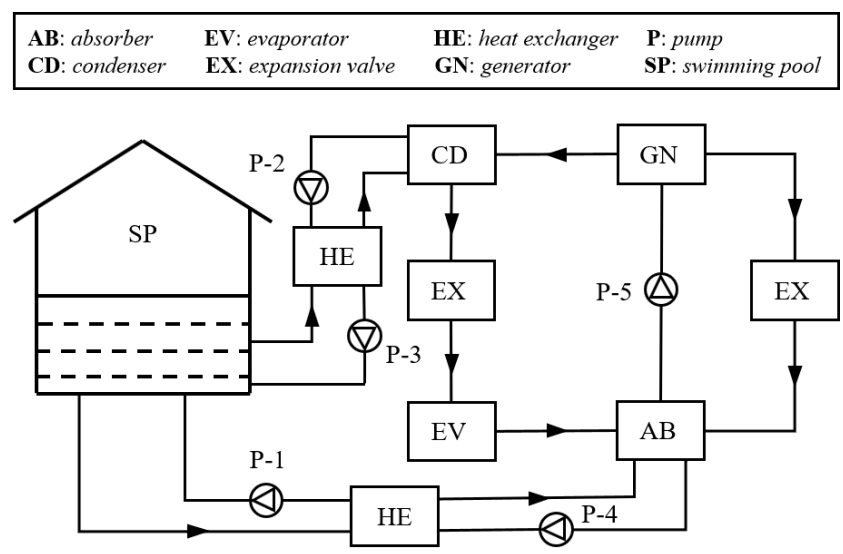

Fig. 5 ISP heating system with absorption heat pump dehumidified air returned to the swimming pool facility, and thus the energy use for handling the outdoor fresh air was reduced. It was concluded that the initial investment of such an open absorption heat pump might be paid back in four to five years, if it was applied to the ISPs in Sweden. These results indicated that this application was economically feasible in some countries.

Similarly, Lazzarin and Longo (1996) proposed an opencycled heat pump system using heat recovery technology to provide heat for an ISP, in which chemical dehumidification was adopted in the exhausted air. It was reported that the proposed heating system was cheaper and simpler than but had nearly the same energy-saving potential as - a compressor-driven heat pump system. Furthermore, Johansson and Westerlund (2001) compared the performance of the ISP heating system using a mechanical heat pump with those of an open absorption system and an air heater system. The authors concluded that the energy use of the system with the compressor-driven heat pump and that of the open absorption system were reduced by $14 \%$ and $20 \%$, respecttively, in comparison with the air heater system. However, they reported that the energy use of the system adopting the compressor-driven heat pump and that of the open absorption system would increase, if the temperature in the building increased. Consequently, in that case, the air heater system would be considered the primary selection to provide heat for the ISP.

\section{(b) Heat pump dehumidifier}

Another heat pump technology applied in ISPs is to use a heat pump dehumidifier. Figure 6 shows a schematic of an ISP heating system with a heat pump dehumidifier, which was developed by Sun et al. (2011). The heat pump dehumidifier had two functions: (1) to recover the latent heat resulting from indoor wet air; and (2) to provide heat 


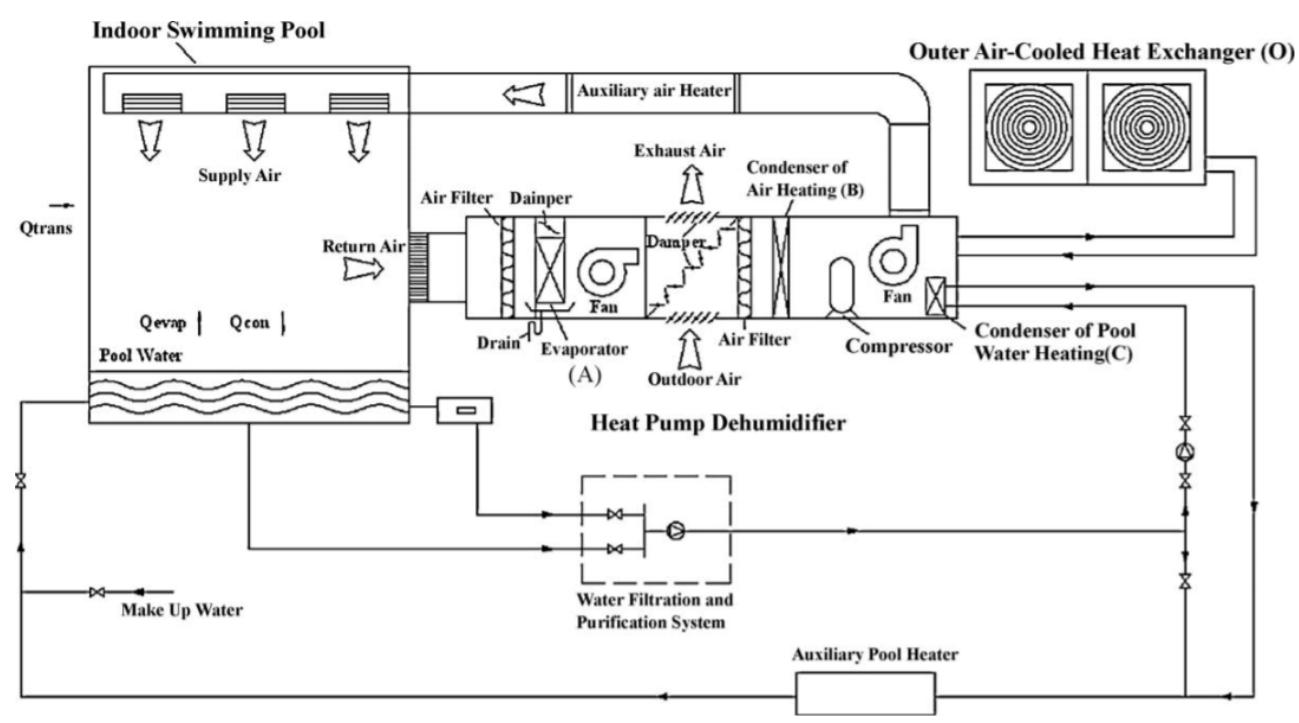

Fig. 6 ISP heating system with heat pump dehumidifier (Sun et al. 2011; reprinted with permission @2011 Elsevier)

for the indoor air and the swimming pool. The switch of these two modes was realized by changing the "on/off" state of the valves in the system. The main difference between this system and the open absorption system was that indoor air was dried by the evaporator in this system, while it was dried by the absorber in the open absorption system. The system's performance was evaluated, and it was concluded that the system had good energy and economic savings potential in comparison with a conventional system (i.e. the system combining a conventional dehumidifier with an electric boiler). Besides, the payback period of the system was approximately 1.1 years.

\section{(c) Solar assisted heat pump}

To enhance the energy-saving potential of heat pumps, solar assisted heat pumps have been proposed (Amin and Hawlader 2013; Mohanraj et al. 2018). A few researchers have explored the energy-saving potential of the solar assisted heat pump applied in ISPs. Figure 7 shows the schematic of an ISP heating system using a solar-assisted heat pump developed by Tagliafico et al. (2012). Two operating modes were considered in this system. In the first operating mode, the by-pass pipes were closed, and the outlet water of the solar collector was supplied into the evaporator. Thus, the evaporator of the heat pump operated at a higher environmental temperature than a traditional heat pump. This led to a higher coefficient of performance (COP). In the second operating mode, the heat pump was turned off, and the by-pass pipes were open. The outlet water of the solar collector was directly supplied into the water tank, to satisfy the heating requirement of the ISP. The opening and closing of the by-pass pipes were realized by the switch of the valves. When the inlet water temperature of the solar collector was between $4{ }^{\circ} \mathrm{C}$ and $18{ }^{\circ} \mathrm{C}$, the system would

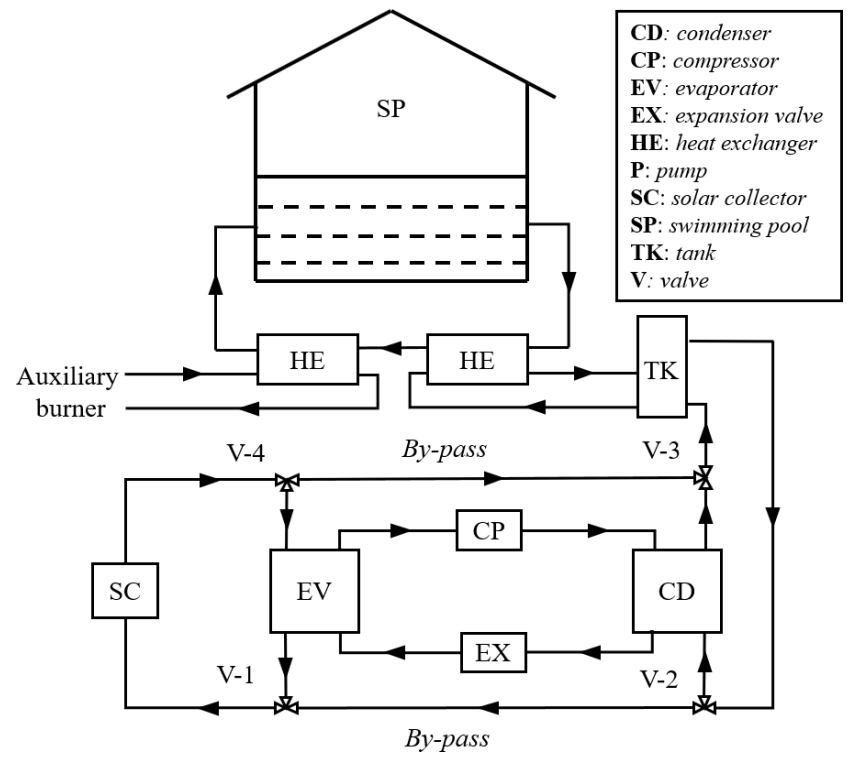

Fig. 7 ISP heating system with solar-assisted heat pump (Tagliafico et al. 2012; reprinted with permission (C2012 Elsevier)

operate in the first mode; and when it was higher than $18{ }^{\circ} \mathrm{C}$, the system would operate in the second mode. The energysaving potential of the proposed heating system was evaluated and found to be a function of degree days. Chow et al. (2012) and Bai et al. (2012) evaluated the economic performance of a solar-assisted heat pump for providing heat for an ISP in winter. In this system, the solar collectors could be used to provide heat for the ISP by means of a water storage tank. The control for the "on/off" of the associated pumps in this loop was realized by the water difference between the outlet water temperature of the collector and the lower end temperature of the storage tank. If the temperature difference was between $2{ }^{\circ} \mathrm{C}$ and $10^{\circ} \mathrm{C}$, the associated pumps would be turned on; otherwise, they would be turned off. The heat 
pump was responsible for the space heating. It would also be used for heating the water of the pool when the solar irradiance was weak. The authors concluded that the COP of the system could reach up to 4.5 , and the initial investment of the system could be paid back in less than five years.

\subsubsection{Waste heat recovery technology}

Waste heat recovery can effectively improve the energy and economic performance of a system, and thus it has been extensively used in many fields, such as in air pre-purification systems (Tong et al. 2018) and vehicle engines (Lan et al. 2018). It has also gained application in ISP heating systems. For example, Oró et al. (2018) used the waste heat produced by a liquid-cooled data center to heat an ISP, shown in Figure 8 . The heat produced by the data center would be offered to the ISP. Meanwhile, the cold water from the ISP could be used to cool the data center. The heat exchange between the data center and the ISP was realized by the heat exchanger. If the inlet water temperature was higher than the set value (e.g. $20^{\circ} \mathrm{C}$ ), the cooling system would be turned on; otherwise, it would be turned off. If the water temperature of the pool was lower than the set value (e.g. $27^{\circ} \mathrm{C}$ ), the boiler would be turned on; otherwise, it would be turned off. The economic performance of the system was evaluated, and it was found that the operating cost of the system was reduced by $18 \%$. An ISP heating system that recovered the waste heat from a chiller in an ice rink was proposed by Kuyumcu et al. (2016). The evaporator of the chiller was used to cool the ice rink down, and the heat from the condenser of the evaporator would be stored in an underground storage tank. The heat stored in this tank would be released to the evaporator of a heat pump. This would provide a high-temperature environment for the evaporator, leading to a high COP of the heat pump. The condenser of the heat pump was used to offer heat for the ISP. The authors performed a parametric study of the heating system, based on an analytical model to identify the optimal ice rink size. Finally, the authors reported that the optimal ice rink size was $475 \mathrm{~m}^{2}$, when the proposed heating system was used in an ISP with an area of $625 \mathrm{~m}^{2}$.

\subsubsection{Geothermal energy technology}

Geothermal energy is an environmentally friendly source of renewable energy, which has the merits of stability and high capacity (Hou et al. 2018). In addition, unlike other renewable energies, such as solar and wind, geothermal energy is not easily influenced by the variations in weather and seasons (Moya et al. 2018). Therefore, this energy source can be regarded as reliable for providing heat for ISPs. A typical heating technique for using the geothermal energy is ground-source heat pump. Figure 9 shows the schematic diagram of an ISP heating system with a ground-source heat pump. The system mainly comprises a ground heat exchanger, heat pump, pump, heat exchanger, and ISP. In summer seasons, the extra heat from the ISP will be stored into the ground by the ground heat exchanger. In winter seasons, the stored heat will be extracted from the ground heat exchanger and offered to the ISP. The typical subcomponents of the heat pump include the condenser, expansion valve, evaporator, and compressor. As shown in Figure 7 and Figure 12, the refrigerant will be cycled among these four components. In summer seasons, the condenser will connect with the side of the ground heat exchanger, and the evaporator will connect with the side of the ISP. In winter seasons, the evaporator will connect with the side of the ground heat exchanger, and the condenser will connect with the side of the ISP. A geothermal plant to supply heat for an ISP in Naples, Italy, was suggested by Barbato et al. (2018). In that study, the results of the cost analysis indicated that the proposed system was economically feasible, because the payback period of the system was 15.4 years. However, this period of 15.4 years might be too long, and thus necessary maintenance should be conducted in a fixed period to ensure the normal operation of the system. In addition, this

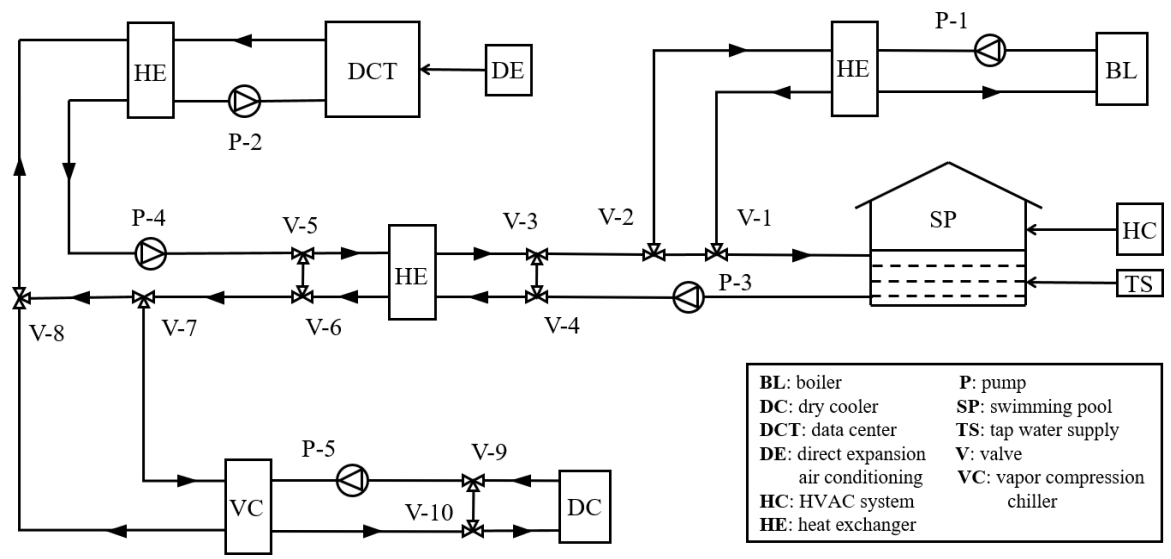

Fig. 8 ISP heating system with the use of the waste heat from a data center (Oró et al. 2018; reprinted with permission @2018 Elsevier) 


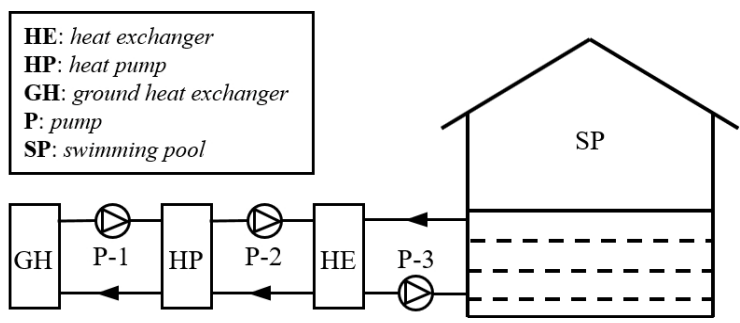

Fig. 9 ISP heating system with ground-source heat pump

study just calculated the possible cost according to the heating load of the ISPs. A detailed design and control of the system might not be presented, and thus the calculated results might just be related to an initial evaluation of the application of geothermal energy technology in an ISP heating system.

\subsubsection{Cogeneration technology}

Cogeneration, also called "Combined heat and power", is a technology that utilizes multiple components to integrate an advanced system for offering heat and electricity. Cogeneration technology has been applied in ISPs to satisfy the heating and electricity demands. Facão and Oliveira (2006) proposed a cogeneration system, comprising solar collector, boiler, evaporator, turbine, electric generator, and condenser in Lisbon, Portugal. The schematic diagram of the congregation system was shown in Figure 10. The solar collector and boiler were used to offer a suitable operating environment for the evaporator. The turbine and electric generator were used to produce the electricity. The condenser was used to provide heat for the ISP, and the heat was offered to the water of the pool and the space in the ISP. The economic performance of the system was found to be considerable when the solar collector area was between $10 \mathrm{~m}^{2}$ and $20 \mathrm{~m}^{2}$. Delmastro et al. (2015) evaluated the performance of a biomass cogeneration system connected to the district heating network in Torino, Italy. The produced heat and electricity from the system were offered to the ISP. It was concluded that the share of the renewable energy sources would be improved, and the use of fossil fuels would be reduced, when the designed system was used. In addition, Wang et al. (2019) analyzed the performance of a

\begin{tabular}{|llll|}
\hline BL: boiler & EV: evaporator & P: pump & SP: swimming pool \\
CD: condenser & HE: heat exchanger & SC: solar collector & TB: turbine \\
\hline
\end{tabular}

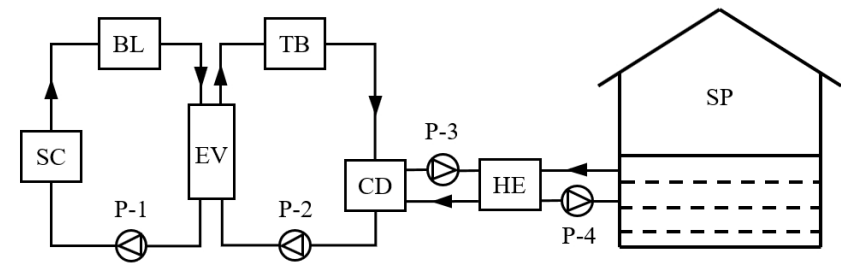

Fig. 10 ISP heating system with cogeneration technology (Facão and Oliveira 2006; reprinted with permission (02006 Oxford University Press) cogeneration system with PV/T used for an ISP in Bari, Italy. The system was found to satisfy $38.2 \%$ of the electricity demand, $27.3 \%$ of the space heating demand, and $53.8 \%$ of the hot water demand.

\subsection{Outdoor swimming pool heating techniques}

OSP heating techniques are utilized to maintain a suitable water temperature for a pool, within a comfortable thermal range. This section presents the current heating techniques applied in OSPs, including solar collector, heat pump, PCM storage, geothermal energy, biomass heater, and waste heat recovery technologies. In the following, a brief overview of the mentioned heat supply technologies is presented.

\subsubsection{Solar collector technology}

Solar collectors have been widely used in OSP heating systems, due to their considerable energy-saving potential. A description of the use of solar collectors in OSP heating systems refers to Section 4.2.1 and Figure 3. Different investigations of the use of solar collector technology are presented as follows. Yadav and Tiwari (1987) proposed the concept of adopting solar collectors with heat exchangers to provide heat for an OSP. The authors found that the water temperature of the OSP increases with the increase in water flowrate, solar collector area and heat exchanger length (Yadav and Tiwari 1987). Further, an experimental study of an OSP heating system with solar collectors in Germany showed that this system was economically competitive when compared with a conventional heating system (Croy and Peuser 1994). The results showed that, in the cold season, around 250 to $300 \mathrm{kWh} / \mathrm{m}^{2}$ solar energy could be used to supply heat for OSPs. In India, a heating system with solar collectors was designed by Dang (1986), to supply heat for an OSP. The author discovered that the calculated energy efficiency of the solar collectors could reach up to 53.3\%. However, for American conditions in the 1990s, the life-cycle analysis of adopting solar collectors to supply heat for an OSP in a university indicated that this heating system might be not be economically feasible over a period of ten years (Alkhamis and Sherif 1992).

A few researchers have focused on the development of energy models for OSP heating systems with solar collectors. For example, Rakopoulos and Vazeos (1987) developed an energy model for an OSP heating system with solar collectors. Based on the measured data for five OSPs heated by solar collectors in Switzerland, Molineaux et al. (1994a) adopted multilinear regressions to identify the empirical parameters in the heating system models. Furthermore, the same authors reported that the mean daily efficiency of the solar collectors in this system could reach up to $60 \%$, if the system operated in optimal conditions (Molineaux et al. 1994b). 
Haaf et al. (1994) developed a simplified model of an OSP heating system with solar collectors, which had the merits of short calculation time and good user-friendliness.

Many studies have also been presented, to enhance the performance of OSP heating systems. The utilization of a low flow rate circulation pump is an efficient measure to enhance a system's energy efficiency. The effect of reducing the flow rate on the performance of a solar collector heating system adopted in an OSP was investigated by Cunio and Sproul (2012), who found that the solar collector's efficiency was only reduced by $10 \%-15 \%$ when the flow rate was decreased by up to $75 \%$, leading to a reduction in the system's energy use of more than $80 \%$. In addition, a simulation study on the effect of a low flow rate circulation pump on the performance of a solar collector with an area of $20.5 \mathrm{~m}^{2}$ for an OSP with an area of $36 \mathrm{~m}^{2}$ was presented in the study of Zhao et al. (2018). They found that $0.016 \mathrm{~kg} /\left(\mathrm{s} \cdot \mathrm{m}^{2}\right)$ was the optimal mass flow rate for each unit collector area, in which an energy-saving ratio of $60 \%$ could be achieved. Adjusting the set-point temperature of swimming pools is another approach for enhancing the performance of OSP heating systems. For example, Hahne and Kübler (1994), who conducted a simulation study of an OSP heating system with solar collectors, found that the energy efficiency of the system could be increased when the set-point water temperature of the swimming pool was reduced within a reasonable range, such as from $24^{\circ} \mathrm{C}$ to $22^{\circ} \mathrm{C}$.

In addition, $\mathrm{PV} / \mathrm{T}$ plants that can covert the solar energy into both electricity and thermal energy (Furukakoi et al. 2018) can improve the performance of OSP heating systems. The performance of an OSP heating system with $\mathrm{PV} / \mathrm{T}$, shown in Figure 11, was assessed by Buonomano et al. (2015). In this study, the authors discovered that the improvement in the energy performance of the system was remarkable when the PV/T was used. They also discovered that, due to the high initial investment in the system, necessary incentive policies were needed to promote the use of the system. Yandri (2017) reported that the energy efficiency of an OSP heating system with PV/T could be effectively improved by integrating Joule heating, which was an internal heating technology that could produce heat through an electrical conductor. Further, Clot et al. (2017)

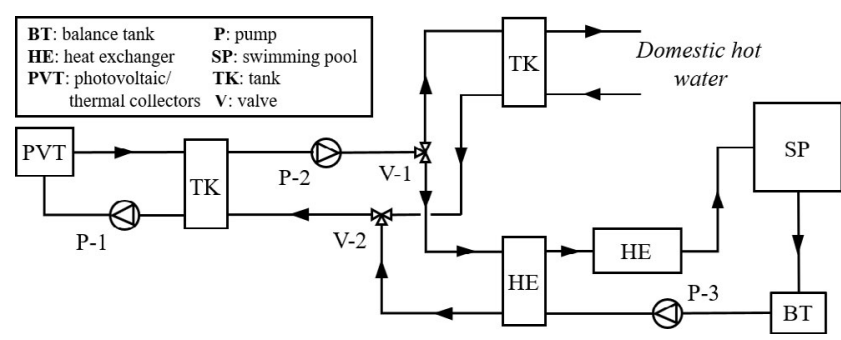

Fig. 11 OSP heating system with PV/T (Buonomano et al. 2015; reprinted with permission (02015 Elsevier) proposed a concept of submerging the PV/T in the water of the OSP. This concept solved the difficulty of finding enough space to install the PV/T. A simulation, using the submerged $\mathrm{PV} / \mathrm{T}$ in an OSP with a surface area of $60 \mathrm{~m}^{2}$ and a volume of $75 \mathrm{~m}^{3}$ was conducted in Rome, Italy. It was found that nearly 10 MWh electricity could be produced when the system was used.

\subsubsection{Heat pump technology}

Heat pumps have been applied to OSP heating systems, and they are only used to heat the water of the pool. Figure 12 shows the schematic diagram of an OSP heating system with air-source heat pump. The system mainly comprises fan, evaporator, compressor, condenser, expansion valve, and OSP. The fan will cycle the ambient air that exchange the heat with the refrigerant in the evaporator. The compressor will be used to increase the pressure of the refringent from the evaporator. The refrigerant with high pressure will be input into the condenser and exchange heat with the cold water from the OSP. The hot water will be supplied into the OSP. The refrigerant leaving the condenser will be input into the expansion valve and the pressure of the refrigerant will be reduced. A life-cycle cost analysis of using heat pumps to supply heat for an OSP in South Africa was performed in the study of Greyvenstein and Meyer (1991). The results indicated that using heat pumps to provide heat for an OSP was more economically beneficial than using solar collectors. The reason might be that the capital cost of using solar collectors was greater than that of using heat pumps. In the studies of Lam and Chan $(2001,2003)$ and Chan and Lam (2003), heat pumps were used to provide heat for an OSP of a five-star hotel in Hong Kong. They concluded that the energy cost for the heating system with heat pumps with a COP of 3.5 could be reduced by HK\$275,700 in a ten-year life cycle, in comparison with that of a conventional system such as electrical or gas heaters.

\subsubsection{PCM storage technology}

Energy storage technology allows energy to be stored during

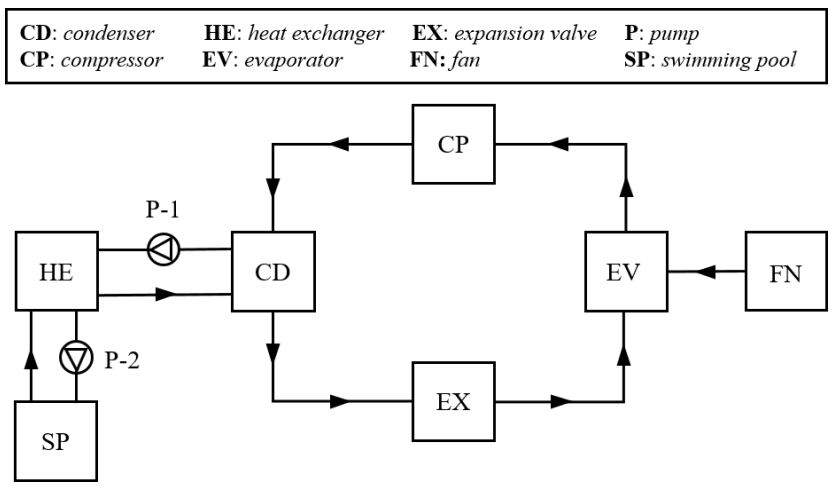

Fig. 12 OSP heating system with air-source heat pump 
low demand or high renewable energy generation periods, and to be discharged during high demand or low renewable energy production periods (Li et al. 2015; Argyrou et al. 2018; Du et al. 2019). This fact enables energy storage technology to be broadly applied in renewable energy applications. Compared with other energy storage media, phase change materials (PCMs) have the merits of high energy storage density and nearly constant temperature during the phase transition process (Xu et al. 2017, 2018; Aketouane et al. 2018; Li et al. 2020b). Thus, they have been extensively adopted in many fields, such as domestic hot water systems (Gorzin et al. 2018), building cooling systems (Bourne and Novoselac 2015; Panchabikesan et al. 2020), and battery thermal management systems (Li et al. 2018a). Recently, researchers have started to use PCM storage in OSP heating systems. For example, Zsembinszki et al. (2012) compared two methods of applying PCMs in OSPs: (1) to install PCM panels in the swimming pool walls, and (2) to use PCM storage tanks to supply heat for OSPs. They concluded that the latter was better than the former, because the discharging time of the stored heat could be well controlled. Furthermore, Li et al. $(2018 b, c)$ proposed an OSP heating system where air-source heat pumps were used, together with PCM storage tanks, as shown in Figure 13. The "on/off" controllers would be used to control the open and closed states of the airsource heat pumps and their associated pumps, according to the formulated time schedule and setting temperature values. During the electric off-peak period, the air-source heat pumps and their associated pumps would be first opened to store heat in the PCM storage tank. When the temperature of the storage tank reached the set value (e.g. $60^{\circ} \mathrm{C}$ ), they would be closed. Then, they would be opened again to preheat the water of the pool at the formulated moment. When the water of the pool reached the set value (e.g. $28.5^{\circ} \mathrm{C}$ ), they would be closed. In addition, during the open period of the OSP, the PI controller was used to maintain the water of the pool within a comfortable thermal

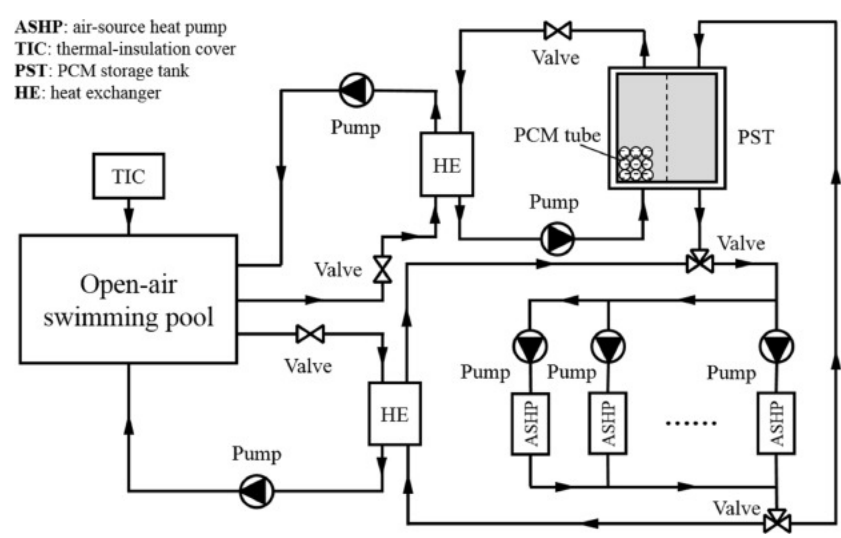

Fig. 13 OSP heating system proposed in the study of Li et al. (2020b; reprinted with permission @2020 Elsevier) range (e.g. around $28^{\circ} \mathrm{C}$ ). The function of the PCM storage tank was to shift the electricity use from the on-peak to the off-peak period and thereby brought considerable economic benefits. The results indicated that the proposed heating system was economically and technically feasible.

\subsubsection{Geothermal energy technology}

Geothermal energy has also gained application in OSPs. A description of the use of the geothermal energy technology in OSP heating systems refers to Section 4.2.4 and Figure 9. For example, Somwanshi et al. (2013) proposed an OSP heating system, which collected heat from the soil at a depth of four meters. The simulation results of this system indicated that the water temperature of the pool could be maintained between $22{ }^{\circ} \mathrm{C}$ and $27^{\circ} \mathrm{C}$ in four different climatic regions, and thereby the proposed heating system was technically feasible. However, the calculation results were based on heat transfer models, and detailed design and control strategies were not considered in this study. In addition, the proposed system might be technically feasible, but it might not be economically feasible. An economic analysis of the system, based on the proposed suitable design and control strategies, should be conducted.

\subsubsection{Biomass heater technology}

Biomass is a renewable energy technology that has the merits of being approximately carbon neutral and abundant in many sources (Bajwa et al. 2018). Figure 14 shows an OSP heating system with biomass heater. The biomass (e.g. animal and agriculture residue) is input into the burner. The fan will be used to blow the air into the burner. The mixture of biomass and air will be ignited. The heat resulted from the burning will be transferred to the OSP by the heat exchanger. Based on this technology, Katsaprakakis (2015) proposed two OSP heating systems: (1) using biomass heaters and (2) using a combination of biomass heaters and solar collectors. In the first system, the required heat of the OSP came totally from the biomass heater. In the second system, the required heat of the OSP came from both solar collectors and biomass heaters. If the temperature of the solar collectors was $4{ }^{\circ} \mathrm{C}$ higher than the water temperature of the pool, the associated heat pump of the solar collector would be turned on; otherwise, it would be turned off. The biomass heater would be opened when the solar collector could not offer enough heat to the water of the OSP. The economic performances of these two systems adopted in OSPs in Greece were evaluated. The authors reported that the operating costs of these proposed systems were significantly reduced in comparison with the conventional systems that adopted expensive diesel oil. In addition, the payback period of these systems was less than five years. 

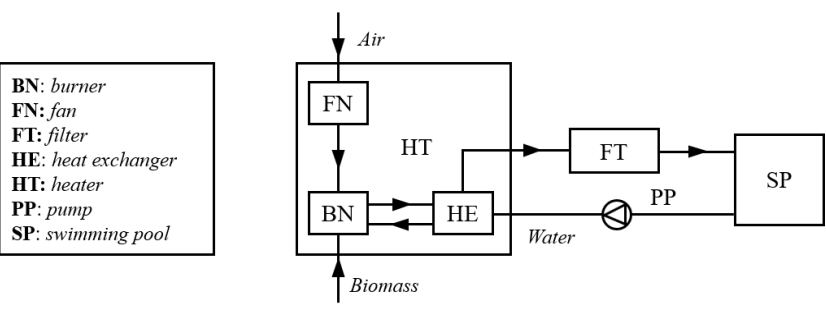

Fig. 14 OSP heating system with biomass heater

\subsubsection{Waste heat recovery technology}

Waste heat recovery techniques are also found to supply heat for OSPs. A description of the use of waste heat recovery technology in OSP heating systems refers to Section 4.2.3 and Figure 8. For example, Borge et al. (2011) showed that an OSP could be used as a heat sink for air-conditioning systems and thereby reduce the heat demand of OSPs and simultaneously enhance the energy efficiency of airconditioning systems. Furthermore, Harrington and Modera (2013) conducted a feasibility study on rejecting waste heat from air-conditioning systems into an OSP in California. This could not only offer heat for the OSP but also reduce the cooling energy use and peak demand of the buildings. They concluded that the energy use for single-family cooling purposes could be reduced by $25 \%-30 \%$, when the proposed system was applied.

\section{Discussion on practical and possible techniques for swimming pool applications}

Section 4 presented the swimming pool heating techniques from the existing literature. However, some key techniques that can be applied for swimming pool applications might not be reported in the existing literature. Discussion of these techniques is valuable, and thus the practical and possible techniques for swimming pool applications are presented in this section. The details of the discussion are shown below.

\subsection{Practical techniques in engineering projects}

The practical techniques in engineering projects for swimming pool applications are very important and worthy of review. However, in current literature, few practical engineering projects for swimming pool heating applications have been reported. More practical engineering projects should be investigated and presented in the literature. Scholars should conduct more investigations of swimming pool heating applications from practical aspects. Based on the authors' current information, a complicated heating system with a heat pump has been applied in an ISP in Norway. The heat pump is used to provide heat for the water of the pool and to satisfy the heating and ventilation load for the buildings. The heat pump also provides heat for showering and connects with geothermal heat storage devices. In addition, currently there are some successful companies that have produced different equipment to offer heat for the swimming pool facilities. For example, a company called Degaulle completed a project for an Indonesia hotel, in which four heat pumps were used to offer heat for the facilities; and a drug disinfection system and six sand filters were used to play the role in disinfecting and filtering, respectively (Degaulle 2020b). This company also completed a project for a Vietnam hotel, in which four heat pumps, a drug disinfection system and eight sand filters were used (Degaulle 2020a). Further, a project titled Holmen Indoor Swimming Pool, Asker has been completed (Holmen 2020). This ISP heating system comprised the PV panels with the surface area of $650 \mathrm{~m}^{2}$, solar collectors with the surface area of $650 \mathrm{~m}^{2}, 15$ geothermal wells, and five heat pumps. PV panels were used to provide heat and electricity for the facility. The annual electricity produced by PV panels were 73,000 kWh, which satisfied around $12 \%$ of the annual electricity demand of the facility. Solar collectors were used to offer hot water. Geothermal wells were used to recover the waste heat from grey water. The recovered heat would be offered to the facility by heat pumps. Hence, it could be found that, in practical applications, if multiple heating techniques were used together, they might effectively enhance the performance of the system. However, in current literature, most scholars mainly focused on single heating techniques; therefore, more investigations into multiple heating techniques should be conducted.

\subsection{Possible techniques for swimming pool applications}

Section 4 presented the ISP and OSP heating techniques from the existing literature. It can be seen that the currently investigated ISP heating techniques include solar collector, heat pump, waste heat recovery, geothermal energy, and cogeneration technologies; meanwhile, the currently investigated OSP heating techniques include solar collector, heat pump, PCM storage, geothermal energy, biomass heater, and waste heat recovery technologies. The solar collector, heat pump, waste heat recovery, and geothermal energy technologies have been investigated and presented in the literature for both ISP and OSP applications. Hence, many technologies could be used in both ISP and OSP applications. However, considering the difference between ISP and OSP heating techniques described at the beginning of Section 4, the design of common techniques should consider two key issues: (1) the annual operating time of an ISP technique is longer than that of an OSP technique; (2) heating load including ventilation load should be considered in ISP 
techniques, while it is not considered in OSP techniques. In fact, the PCM storage and biomass heaters presented in OSP heating techniques can be used for ISPs, while the mentioned design suggestions should be considered. In addition, the cogeneration presented in ISP heating techniques can be used for OSPs. It should be noted that fuel cells that can effectively convert the chemical energy into electricity can be used in cogeneration techniques for both ISPs and OSPs. Currently, few studies have focused on investigating the use of fuel cells in ISP and OSP heating systems. Based on the above discussion, more studies should be conducted regarding the use of PCM storage and biomass heater techniques for ISP heating systems, using cogeneration techniques for OSP heating systems and fuel cells for both ISP and OSP heating systems.

\section{Conclusions and future possible research opportunities}

This review summarized the heat transfer model for swimming pools, and passive and active technologies for swimming pool heating systems. Different equations and approaches for calculating the components in the heat transfer model of the swimming pool, including heat loss from evaporative, convective, radiative, conductive, refilling water and heat gained from the sun, were summarized. The active heating technologies for ISPs were classified as solar collector, heat pump, waste heat recovery, geothermal energy, and cogeneration technologies. The active heating technologies for OSPs were classified as solar collector, heat pump, PCM storage, geothermal energy, biomass, and waste heat recovery technologies. A discussion was presented on the practical and possible heating techniques for swimming pool applications. Based on the reviewed literature, future possible research opportunities were proposed, providing a meaningful guideline for researchers, government, and building owners to develop feasible swimming pool heating systems. The proposed research opportunities were shown as follows:

- Although mathematical models for describing the heat transfer process in swimming pools have been proposed, the precondition of using this model is the assumption that one temperature point is regarded as the water temperature of the entire pool. In fact, the water temperature varies in different regions of the pool. For example, in the OSP model, shading of the building will affect the solar energy that different regions of the pool can obtain. Therefore, future research is necessary on the influence of temperature distribution in swimming pools on heating system control and thermal comfort.

- Few studies have presented the heat gained from the bodies of swimmers in the heat transfer model. The activities and number of swimmers will affect the heat exchange between swimmers and the pool water. For ISPs, the activities and number of swimmers will also affect the heating load of the facilities. Hence, it is suggested that the effect of the heat gain from the bodies of swimmers on the heat transfer model should be investigated in future studies.

- The energy consumption of swimming pool facilities is affected by many factors, such as location, climate, and operating time. Current surveys for collecting data about the energy consumption of swimming pool facilities are limited. More surveys or simulation studies should be conducted to investigate this. Necessary comparisons between ISPs and OSPs with similar dimensions and same operating conditions might be made.

- In the current studies, a thermal-insulation cover was placed on the surface of the pool when it was closed. This could prevent heat loss from the surface, such as evaporative and convective heat loss. However, thermal-insulation covers should also be used on the walls and bottom of the pool, contributing to reducing conductive heat loss during the pool's both open and closed periods.

- During a pool's unoccupied period, heating applications such as solar collectors and heat pumps might not be used to provide heat for the pool. Thermal energy storage technologies such as PCM should be used to store the heat from these applications. For solar collectors, the heat can be stored in thermal energy storage devices during the period when solar irradiation is adequate, and no heat is needed for the pool. For heat pumps, the heat can be stored in thermal energy devices during the period when the electricity price is favorable, and no heat is needed for the pool.

- Current investigations into the use of geothermal energy technology in both ISP and OSP heating systems have mainly focused on an initial evaluation of the system. They have analyzed the performance of the system based on simple calculations. Suitable design and control strategies for systems with geothermal energy technology are still lacking. In addition, it is still necessary to consider the issue of maintaining the long-term operation of systems with geothermal energy technology. Initial and maintenance costs of a system with geothermal energy technology were high for maintaining long-term operation. Hence, more investigations should be conducted, to enhance the economic benefits of this system.

- Most swimming pool heating technologies consider the use of solar energy and heat pumps. However, more attention should be focused on other efficient techniques, such as geothermal energy and biomass energy technologies.

- Many scholars only propose a concept for heating technologies in swimming pools and perform a simple 
feasibility analysis for the proposed system. Details about the proper control and operation of the proposed systems are lacking, because they may have a significant effect on the real achieved results.

- A few studies presented the optimization and optimal control for the studied swimming pool heating systems. However, multi-objective optimizations should be performed, considering multi-aspects, such as energy, economics, exergy, thermal comfort, and environmental performance.

- Due to abundant solar irradiance and high ambient temperature in summer, the water temperature of the OSP might be high, even beyond the thermal comfortable range of swimmers. It is necessary to use cooling techniques to cool the pool water down, and the simplest technique might be to use the cooling capacity of the fresh cold water. The extra heat of the OSP can be used in the aspects of domestic hot water and showering.

\section{Acknowledgements}

The work described in this paper was supported by a grant from the Research Grants Council of the Hong Kong Special Administrative Region, China (No. 11208918). The authors appreciated the support of funding from the Department of Energy and Process Engineering of the Norwegian University of Science and Technology, Norway.

Funding note: Open access funding provided by NTNU Norwegian University of Science and Technology (incl St. Olavs Hospital - Trondheim University Hospital).

Open Access: This article is licensed under a Creative Commons Attribution 4.0 International License, which permits use, sharing, adaptation, distribution and reproduction in any medium or format, as long as you give appropriate credit to the original author(s) and the source, provide a link to the Creative Commons licence, and indicate if changes were made.

The images or other third party material in this article are included in the article's Creative Commons licence, unless indicated otherwise in a credit line to the material. If material is not included in the article's Creative Commons licence and your intended use is not permitted by statutory regulation or exceeds the permitted use, you will need to obtain permission directly from the copyright holder.

To view a copy of this licence, visit http://creativecommons.org/licenses/by/4.0/

\section{References}

Abdel-Khalik SI (1976). Heat removal factor for a flat-plate solar collector with a serpentine tube. Solar Energy, 18: 59-64.
Aketouane Z, Malha M, Bruneau D, Bah A, Michel B, Asbik M, Ansari O (2018). Energy savings potential by integrating Phase Change Material into hollow bricks: The case of Moroccan buildings. Building Simulation, 11: 1109-1122.

Alkhamis A, Sherif S (1992). Performance analysis of a solar-assisted swimming pool heating system. Energy, 17: 1165-1172.

Amin ZM, Hawlader MNA (2013). A review on solar assisted heat pump systems in Singapore. Renewable and Sustainable Energy Reviews, 26: 286-293.

Argyrou MC, Christodoulides P, Kalogirou SA (2018). Energy storage for electricity generation and related processes: Technologies appraisal and grid scale applications. Renewable and Sustainable Energy Reviews, 94: 804-821.

ASHRAE (2003). ASHRAE Handbook: HVAC Applications. Atlanta: American Society of Heating, Refrigerating and Air-Conditioning Engineers.

Asdrubali F (2009). A scale model to evaluate water evaporation from indoor swimming pools. Energy and Buildings, 41: 311-319.

Bai Y, Chow T-T, Ménézo C, Dupeyrat P (2012). Analysis of a hybrid $\mathrm{PV} /$ thermal solar-assisted heat pump system for sports center water heating application. International Journal of Photoenergy, 2012: 1-13.

Bajwa DS, Peterson T, Sharma N, Shojaeiarani J, Bajwa SG (2018). A review of densified solid biomass for energy production. Renewable and Sustainable Energy Reviews, 96: 296-305.

Barbato M, Cirillo L, Menditto L, Moretti R, Nardini S (2018). Feasibility study of a geothermal energy system for indoor swimming pool in Campi Flegrei area. Thermal Science and Engineering Progress, 6: 421-425.

Bazilian MD, Leenders F, van der Ree B, Prasad D (2001). Photovoltaic cogeneration in the built environment. Solar Energy, 71: 57-69.

Berardi U, Soudian S (2018). Benefits of latent thermal energy storage in the retrofit of Canadian high-rise residential buildings. Building Simulation, 11: 709-723.

Bergman TL, Incropera FP, DeWitt DP, Lavine AS (2011). Fundamentals of Heat and Mass Transfer, 7th edn. Hoboken, NJ, USA: John Wiley \& Sons.

Blázquez JLF, Maestre IR, Gallero FJG, Gómez PÁ (2017). A new practical CFD-based methodology to calculate the evaporation rate in indoor swimming pools. Energy and Buildings, 149: 133-141.

Blázquez JLF, Maestre IR, González Gallero FJ, Álvarez Gómez P (2018). Experimental test for the estimation of the evaporation rate in indoor swimming pools: Validation of a new CFDbased simulation methodology. Building and Environment, 138: 293-299.

Borge D, Colmenar A, Castro M, Martín S, Sancristobal E (2011). Exergy efficiency analysis in buildings climatized with $\mathrm{LiCl}-\mathrm{H}_{2} \mathrm{O}$ solar cooling systems that use swimming pools as heat sinks. Energy and Buildings, 43: 3161-3172.

Bourne S, Novoselac A (2015). Compact PCM-based thermal stores for shifting peak cooling loads. Building Simulation, 8: 673-688.

Bowen IS (1926). The ratio of heat losses by conduction and by evaporation from any water surface. Physical Review, 27: 779.

Brambley MR, Wells SE (1983). Energy-conservation measures for indoor swimming pools. Energy, 8: 403-418. 
Brook F (1955). Solar Energy Research. Daniels F, Duffle JA (eds). Madison: University of Wisconsin Press.

Buonomano A, de Luca G, Figaj RD, Vanoli L (2015). Dynamic simulation and thermo-economic analysis of a PhotoVoltaic/ Thermal collector heating system for an indoor-outdoor swimming pool. Energy Conversion and Management, 99: 176-192.

Chan WW, Lam JC (2003). Energy-saving supporting tourism sustainability: A case study of hotel swimming pool heat pump. Journal of Sustainable Tourism, 11: 74-83.

Chow TT, Bai Y, Fong KF, Lin Z (2012). Analysis of a solar assisted heat pump system for indoor swimming pool water and space heating. Applied Energy, 100: 309-317.

Ciuman P, Lipska B (2018). Experimental validation of the numerical model of air, heat and moisture flow in an indoor swimming pool. Building and Environment, 145: 1-13.

Clot MR, Rosa-Clot P, Tina GM (2017). Submerged PV solar panel for swimming pools: SP3. Energy Procedia, 134: 567-576.

Croy R, Peuser FA (1994). Experience with solar systems for heating swimming pools in Germany. Solar Energy, 53: 47-52.

Cunio LN, Sproul AB (2012). Performance characterisation and energy savings of uncovered swimming pool solar collectors under reduced flow rate conditions. Solar Energy, 86: 1511-1517.

Czarnecki JT (1963). A method of heating swimming pools by solar energy. Solar Energy, 7: 3-7.

Dang A (1986). A parametric study of swimming pool heating-I. Energy Conversion and Management, 26: 27-31.

Degaulle (2020a). A project for a Vietnam hotel. Available at https:// www.degaullepool.com/vietnam-hotel-swimming-pool-project.html.

Degaulle (2020b). A project for an Indonesia hotel. Available at https://www.degaullepool.com/indonesia-hotel-swimming-poolproject.html.

Delmastro C, Mutani G, Schranz L (2015). Advantages of coupling a woody biomass cogeneration plant with a district heating network for a sustainable built environment: A case study in luserna San Giovanni (Torino, Italy). Energy Procedia, 78: 794-799.

Drissi Lamrhari E-H, Benhamou B (2018). Thermal behavior and energy saving analysis of a flat with different energy efficiency measures in six climates. Building Simulation, 11: 1123-1144.

Du Y, Mak CM, Liu J, Xia Q, Niu J, Kwok KCS (2017). Effects of lift-up design on pedestrian level wind comfort in different building configurations under three wind directions. Building and Environment, 117: 84-99.

Du Y, Mak CM, Ai Z (2018). Modelling of pedestrian level wind environment on a high-quality mesh: A case study for the HKPolyU campus. Environmental Modelling \& Software, 103: 105-119.

Du R, Li W, Xiong T, Yang X, Wang Y, Shah KW (2019). Numerical investigation on the melting of nanoparticle-enhanced PCM in latent heat energy storage unit with spiral coil heat exchanger. Building Simulation, 12: 869-879.

Du Y, Blocken B, Pirker S (2020). A novel approach to simulate pollutant dispersion in the built environment: Transport-based recurrence CFD. Building and Environment, 170: 106604.

EU (2020). EU 2030 climate \& energy framework. Available at https://ec.europa.eu/clima/policies/strategies/2030_en.

Facão, J, Oliveira AC (2006). Analysis of a micro-cogeneration system using hybrid solar/gas collectors. International Journal of LowCarbon Technologies, 1: 285-297.
Feng X, Yan D, Yu R, Gao Y (2017). Investigation and modelling of the centralized solar domestic hot water system in residential buildings. Building Simulation, 10: 87-96.

Francey JLA, Golding P, Clarke R (1980). Low-cost solar heating of community pools using pool covers. Solar Energy, 25: 407-416.

Furukakoi M, Adewuyi OB, Matayoshi H, Howlader AM, Senjyu T (2018). Multi objective unit commitment with voltage stability and PV uncertainty. Applied Energy, 228: 618-623.

Gorzin M, Hosseini MJ, Ranjbar AA, Bahrampoury R (2018). Investigation of PCM charging for the energy saving of domestic hot water system. Applied Thermal Engineering, 137: 659-668.

Govaer D, Zarmi Y (1981). Analytical evaluation of direct solar heating of swimming pools. Solar Energy, 27: 529-533.

Govaer D (1984). Determining the solar heating of swimming pools by the utilizability method. Solar Energy, 32: 667-669.

Greyvenstein GP, Meyer JP (1991). The viability of heat pumps for the heating of swimming pools in South Africa. Energy, 16: 1031-1037.

Haaf W, Luboschik U, Tesche B (1994). Solar swimming pool heating: Description of a validated model. Solar Energy, 53: 41-46.

Hahne E, Kübler R (1994). Monitoring and simulation of the thermal performance of solar heated outdoor swimming pools. Solar Energy, 53: 9-19.

Hanssen S, Mathisen H (1990). Evaporation from swimming pools. In: Proceedings of the 2nd International Conference on Engineering Aero-and Thermodynamics of Ventilated Rooms (Roomvent'90), Oslo, Norway.

Harkouss F, Fardoun F, Biwole PH (2018). Optimization approaches and climates investigations in NZEB-A review. Building Simulation, 11: 923-952.

Harrington C, Modera M (2013). Swimming pools as heat sinks for air conditioners: California feasibility analysis. Energy and Buildings, 59: 252-264.

Holmen (2020). Holmen indoor Swimming Pool, Asker. Available at https://www.arkitektur.no/holmen-indoor-swimming-pool-aske r?lcid $=1033$.

Hong T, Langevin J, Sun K (2018). Building simulation: Ten challenges. Building Simulation, 11: 871-898.

Hou J, Cao M, Liu P (2018). Development and utilization of geothermal energy in China: Current practices and future strategies. Renewable Energy, 125: 401-412.

ISO/TC 180 (1995). ISO/TC 180/SC 4 N 140. Solar Energy-Heating Systems for Swimming Pools-Design and Installation.

Johansson L, Westerlund L (2001). Energy savings in indoor swimming-pools: comparison between different heat-recovery systems. Applied Energy, 70: 281-303.

Kampel W, Aas B, Bruland A (2013). Energy-use in Norwegian swimming halls. Energy and Buildings, 59: 181-186.

Kampel W, Carlucci S, Aas B, Bruland A (2016). A proposal of energy performance indicators for a reliable benchmark of swimming facilities. Energy and Buildings, 129: 186-198.

Katsaprakakis DA (2015). Comparison of swimming pools alternative passive and active heating systems based on renewable energy sources in Southern Europe. Energy, 81: 738-753.

Kim S, Lee H, Kim H, Jang D-H, Kim H-J, Hur J, Cho Y-S, Hur K (2018). Improvement in policy and proactive interconnection procedure for renewable energy expansion in South Korea. Renewable and Sustainable Energy Reviews, 98: 150-162. 
Kuyumcu ME, Tutumlu H, Yumrutaş R (2016). Performance of a swimming pool heating system by utilizing waste energy rejected from an ice rink with an energy storage tank. Energy Conversion and Management, 121: 349-357.

Lam JC, Chan WW (2001). Life cycle energy cost analysis of heat pump application for hotel swimming pools. Energy Conversion and Management, 42: 1299-1306.

Lam JC, Chan WW (2003). Energy performance of air-to-water and water-to-water heat pumps in hotel applications. Energy Conversion and Management, 44: 1625-1631.

Lan S, Yang Z, Chen R, Stobart R (2018). A dynamic model for thermoelectric generator applied to vehicle waste heat recovery. Applied Energy, 210: 327-338.

Lazzarin RM, Longo GA (1996). Comparison of heat recovery systems in public indoor swimming pools. Applied Thermal Engineering, 16: 561-570.

Lee W-S, Kung C-K (2008). Optimization of heat pump system in indoor swimming pool using particle swarm algorithm. Applied Thermal Engineering, 28: 1647-1653.

Li Y, Zhang Q, Sun X, Du Y, Liao S (2015). Optimization on performance of the latent heat storage unit (LHSU) in telecommunications base stations (TBSs) in China. Energy Procedia, 75: 2119-2124.

Li Y, Du Y, Xu T, Wu H, Zhou X, Ling Z, Zhang Z (2018a). Optimization of thermal management system for Li-ion batteries using phase change material. Applied Thermal Engineering, 131: 766-778.

Li Y, Huang G, Wu H, Xu T (2018b). Feasibility study of a PCM storage tank integrated heating system for outdoor swimming pools during the winter season. Applied Thermal Engineering, 134: 490-500.

Li Y, Huang G, Xu T, Liu X, Wu H (2018c). Optimal design of PCM thermal storage tank and its application for winter available open-air swimming pool. Applied Energy, 209: 224-235.

Li Y, Huang G (2019). Development of an integrated low-carbon heating system for outdoor swimming pools for winter application. In: Proceedings of the 13th REHVA World Congress (CLIMA 2019).

Li Z, Dai J, Chen H, Lin B (2019). An ANN-based fast building energy consumption prediction method for complex architectural form at the early design stage. Building Simulation, 12: 665-681.

Li Y, Ding Z, Du Y (2020a). Techno-economic optimization of open-air swimming pool heating system with PCM storage tank for winter applications. Renewable Energy, 150: 878-890.

Li Y, Ding Z, Shakerin M, Zhang N (2020b). A multi-objective optimal design method for thermal energy storage systems with PCM: A case study for outdoor swimming pool heating application. Journal of Energy Storage, 29: 101371.

Li Y, Zhang N, Ding Z (2020c). Investigation on the energy performance of using air-source heat pump to charge PCM storage tank. Journal of Energy Storage, 28: 101270.

Li C, Li C, Lyu Y, Qiu Z (2020d). Performance of double-circulation water-flow window system as solar collector and indoor heating terminal. Building Simulation, 13: 575-584.

Limane A, Fellouah H, Galanis N (2017). Simulation of airflow with heat and mass transfer in an indoor swimming pool by OpenFOAM. International Journal of Heat and Mass Transfer, 109: 862-878.
Limane A, Fellouah H, Galanis N (2018). Three-dimensional OpenFOAM simulation to evaluate the thermal comfort of occupants, indoor air quality and heat losses inside an indoor swimming pool. Energy and Buildings, 167: 49-68.

Lu T, Lü X, Viljanen M (2014). Prediction of water evaporation rate for indoor swimming hall using neural networks. Energy and Buildings, 81: 268-280.

McKeown D (2009). Swimming Pool Operator's Manual. Toronto: Public Health.

McMillan W (1971). Heat dispersal-Lake trawsfynydd cooling studies. In: Symposium on Freshwater Biology and Electrical Power Generation, Part I, Session 1, pp. 41-80.

MEPC (2020). Typical material used in thermal-insulation covers. Available at https://www.m-ep.co.jp/.

Mohanraj M, Belyayev Y, Jayaraj S, Kaltayev A (2018). Research and developments on solar assisted compression heat pump systems-A comprehensive review (Part A: Modeling and modifications). Renewable and Sustainable Energy Reviews, 83: 90-123.

Molineaux B, Lachal B, Guisan O (1994a). Thermal analysis of five outdoor swimming pools heated by unglazed solar collectors. Solar Energy, 53: 21-26.

Molineaux B, Lachal B, Guisan O (1994b). Thermal analysis of five unglazed solar collector systems for the heating of outdoor swimming pools. Solar Energy, 53: 27-32.

Mousia A, Dimoudi A (2015). Energy performance of open air swimming pools in Greece. Energy and Buildings, 90: 166-172.

Moya D, Aldás C, Kaparaju P (2018). Geothermal energy: Power plant technology and direct heat applications. Renewable and Sustainable Energy Reviews, 94: 889-901.

OMNEXUS (2020). Typical material used in thermal-insulation covers. Available at https://omnexus.specialchem.com/.

Oró E, Allepuz R, Martorell I, Salom J (2018). Design and economic analysis of liquid cooled data centres for waste heat recovery: A case study for an indoor swimming pool. Sustainable Cities and Society, 36: 185-203.

Panaras G, Markogiannaki M, Tolis EI, Sakellaris Y, Bartzis JG (2018). Experimental and theoretical investigation of air exchange rate of an indoor aquatic center. Sustainable Cities and Society, 39: 126-134.

Panchabikesan K, Joybari MM, Haghighat F, Ramalingam V, Ding Y (2020). Feasibility study on the year-round operation of PCM based free cooling systems in tropical climatic conditions. Energy, 192: 116695

Rajagopalan P, Jamei E (2015). Thermal comfort of multiple user groups in indoor aquatic centres. Energy and Buildings, 105: 129-138.

Rakopoulos CD, Vazeos E (1987). A model of the energy fluxes in a solar heated swimming pool and its experimental validation. Energy Conversion and Management, 27: 189-195.

Richter D (1979). Temperatur-und Wärmehaushalt des thermisch belasteten Stechlin-und Nehmitzsees Abhandlung des Meteorologischen Dienstes der DDR Nr. 123. Berlin: AkademieVerlag.

Rohwer C (1931). Evaporation from free water surfaces. Technical Bulletins 163103. US Department of Agriculture.

Romberg TA (1995). Reform in School Mathematics and Authentic Assessment. Albany, NY, USA: State University of New York Press. 
Root DE, Jr (1960). Practical aspects of solar swimming pool heating. Solar Energy, 4: 23-24.

Ruiz E, Martínez PJ (2010). Analysis of an open-air swimming pool solar heating system by using an experimentally validated TRNSYS model. Solar Energy, 84: 116-123.

Sakah M, Diawuo FA, Katzenbach R, Gyamfi S (2017). Towards a sustainable electrification in Ghana: A review of renewable energy deployment policies. Renewable and Sustainable Energy Reviews, 79: 544-557.

Shah MM (2002). Evaluation of available correlations for rate of evaporation from undisturbed water pools to quiet air. $H V A C \& R$ Research, 8: 125-131.

Shah MM (2003). Prediction of evaporation from occupied indoor swimming pools. Energy and Buildings, 35: 707-713.

Shah MM (2012). Improved method for calculating evaporation from indoor water pools. Energy and Buildings, 49: 306-309.

Shah M (2014). Methods for calculation of evaporation from swimming pools and other water surfaces. ASHRAE Transactions, 120(2): 3-17.

Sharifi A, Yamagata Y (2015). Roof ponds as passive heating and cooling systems: A systematic review. Applied Energy, 160: 336-357.

Singh M, Tiwari GN, Yadav YP (1989). Solar energy utilization for heating of indoor swimming pool. Energy Conversion and Management, 29: 239-244.

Smith CC, Löf G, Jones R (1994). Measurement and analysis of evaporation from an inactive outdoor swimming pool. Solar Energy, 53: 3-7.

Somwanshi A, Tiwari AK, Sodha MS (2013). Feasibility of earth heat storage for all weather conditioning of open swimming pool water. Energy Conversion and Management, 68: 89-95.

Sun P, Wu J, Wang R, Xu Y (2011). Analysis of indoor environmental conditions and heat pump energy supply systems in indoor swimming pools. Energy and Buildings, 43: 1071-1080.

Szeicz G, McMonagle RC (1983). The heat balance of urban swimming pools. Solar Energy, 30: 247-259.

Tagliafico LA, Scarpa F, Tagliafico G, Valsuani F (2012). An approach to energy saving assessment of solar assisted heat pumps for swimming pool water heating. Energy and Buildings, 55: 833-840.

Tiwari GN, Sharma SB (1991). Design parameters for indoor swimming-pool heating using solar energy. Energy, 16: 971-975.

Tong LG, Zhang P, Yin SW, Zhang PK, Liu CP, et al. (2018). Waste heat recovery method for the air pre-purification system of an air separation unit. Applied Thermal Engineering, 143: 123-129.

Trianti-Stourna E, Spyropoulou K, Theofylaktos C, Droutsa K, Balaras CA, et al. (1998). Energy conservation strategies for sports centers: Part B. Swimming pools. Energy and Buildings, 27: 123-135.
Uribe D, Bustamante W, Vera S (2018). Potential of perforated exterior louvers to improve the comfort and energy performance of an office space in different climates. Building Simulation, 11: 695-708.

Varming (2020). Difference between passive and active applications. Available at http://www.varming.ie/blog/the-difference-betweenpassive-and-active-design.

Wang K, Herrando M, Pantaleo AM, Markides CN (2019). Thermoeconomic assessment of a PV/T combined heating and power system for University Sport Centre of Bari. Energy Procedia, 158: 1229-1234.

Westerlund L, Dahl J (1994). Use of an open absorption heat-pump for energy conservation in a public swimming-pool. Applied Energy, 49: 275-300.

Winterton RHS (1999). Newton's law of cooling. Contemporary Physics, 40: 205-212.

Woolley J, Harrington C, Modera M (2011). Swimming pools as heat sinks for air conditioners: Model design and experimental validation for natural thermal behavior of the pool. Building and Environment, 46: 187-195.

Wu H, Tang R, Li Z, Zhong H (2009). A mathematical procedure to estimate solar absorptance of shallow water ponds. Energy Conversion and Management, 50: 1828-1833.

Xie H, Gong G, Fu M, Wang P, Li L (2018). A thermodynamic method to calculate energy \& exergy consumption and $\mathrm{CO}_{2}$ emission of building materials based on economic indicator. Building Simulation, 11: 235-244.

Xu T, Li Y, Chen J, Liu J (2017). Preparation and thermal energy storage properties of $\mathrm{LiNO}_{3}-\mathrm{KCl}-\mathrm{NaNO}_{3} /$ expanded graphite composite phase change material. Solar Energy Materials and Solar Cells, 169: 215-221.

Xu T, Li Y, Chen J, Wu H, Zhou X, Zhang Z (2018). Improving thermal management of electronic apparatus with paraffin (PA)/ expanded graphite (EG)/graphene (GN) composite material. Applied Thermal Engineering, 140: 13-22.

Yadav YP, Tiwari GN (1987). Analytical model of solar swimming pool: Transient approach. Energy Conversion and Management, 27: 49-54.

Yandri E (2017). The effect of Joule heating to thermal performance of hybrid PVT collector during electricity generation. Renewable Energy, 111: 344-352.

Zhao J, Bilbao JI, Spooner ED, Sproul AB (2018). Experimental study of a solar pool heating system under lower flow and low pump speed conditions. Renewable Energy, 119: 320-335.

Zsembinszki G, Farid MM, Cabeza LF (2012). Analysis of implementing phase change materials in open-air swimming pools. Solar Energy, 86: 567-577. 